\title{
DEVELOPMENT OF THRESHING SYSTEM IN COMBINE HARVESTER FOR IMPROVING OF ITS PERFORMANCE EFFICIENCY IN RICE THRESHING
}

\author{
Ahmed El-Raie E. Suliman ${ }^{1}$, Abdel-Al, Taieb ${ }^{2}$, Mervat M. Atallah ${ }^{3}$
}

\section{ABSTRACT}

The combine (Class Crop Tiger) which was used in the present study is middle size (2.10 $\mathrm{m}$ cutting width). The axial flow drum was used in this combine. Separation wings were parallel with its axis. So, some improvements could be added to the axial-flow threshing/separating drum to improve the straw flow to reduce blockage, loss and to improve field efficiency and grain yield. So, improving the performance of combine machines during the harvesting operation of cereal crops is important to minimize both grain losses and operational costs.

The main experiments were carried out at Ahmed Ramie Farm, Etai Al Barod, El-Behera Governorate, in order to compare four different types of threshing and separation drums of combine. The experiments were conducted in productive rice crop, variety (Giza 171) in an area of about 4.10 feddans. Specifications of threshing and separation drum before and after development:

1- Design and fabricate three serrated agitator ledge (15, 10 and 7 teeth), so that the passing crop and separation will be easy.

2- The length of threshing and separation is $180 \mathrm{~cm}$, it consists three parts, the first part of the threshing section length $57.5 \mathrm{~cm}$, the second part of the separation section length $90.5 \mathrm{~cm}$, it change the separation section length to $110.5 \mathrm{~cm}$ to increase the grain separation efficiency and the third part of the straw exit section length to $22 \mathrm{~cm}$.

3- The thickness of the separation vane to be $5 \mathrm{~nm}$ instead of $3.5 \mathrm{~min}$.

4- Using steel 60 to overcome the wear of vanes during the separation operation.

\footnotetext{
${ }^{1}$ Prof. of Ag. Eng. Dept., Fc. Of Ag., Cairo University.

2 Assoc. Prof. of Ay. Eng. Dept., Fac. of Ag., Cairo University.

${ }^{3}$ Post graduate student (PhD) Ag. Eng. Dept., Fac. of Ag. Cairo Univ.
} 
Using three levels of cylinder speed as 500, 630 and $803 \mathrm{rpm}$ (17.0, 21.4 and $27.3 \mathrm{~m} / \mathrm{s}$, adjusting the cylinder-concave clearance by using three levels of clearance namely 12.5/5.5, 13/6 and 16/7 n, and using two levels of feeding rate 2000 and $3000 \mathrm{~kg} / \mathrm{h}$. The results showed that:

1- The total grain losses decreased by decreasing both of the feed, rate, operating forward speed, threshing drum speed and the cylinderconcave clearance.

2- The threshing efficiency increased by decreasing the feed rate and operating forward speed, and it decreased by decreasing threshing drum speed, increasing the cylinder-concave clearance.

3- The grain quality increased by decreasing the feed rate, operating forward speed and threshing drum speed, and it decreased by decreasing the cylinder-concave clearance.

4- The cleaning efficiency increased by decreasing the feed rate, operating forward speed and threshing drum speed, and it decreased by increasing the cylinder-concave clearance.

5- The highest values of the actual field capacity at the feed rate $200 \mathrm{~kg} / \mathrm{h} /$ operating forward speed of $1.22 \mathrm{~km} / \mathrm{h} /$ grain moisture content $21 \%$, threshing drum speed of $500 \mathrm{rpm}(17 \mathrm{~m} / \mathrm{s})$ and the cylinderconcave clearance $\left(C_{1}\right)$ of $12.5 / 5.5 \mathrm{~mm}$, was found to be as the developed rotor 7 teeth $(0.489 \mathrm{fed} / \mathrm{h})$, the develop rotor 10 teeth $(0.473 \mathrm{fed} . / \mathrm{h})$, the developed rotor 15 teeth $(0.460 \mathrm{fed} . / \mathrm{h})$ and the original rotor 15 teeth $(0.42 \mathrm{~g}$ fed. $/ \mathrm{h})$.

6- The least values of the required energy at the feed rate of $2000 \mathrm{~kg} / \mathrm{h}$, operating forward speed of $1.22 \mathrm{~km} / \mathrm{h} / \mathrm{grain}$ moisture content of $21 \%$, threshing drum speed of $500 \mathrm{rpm}(17 \mathrm{~m} / \mathrm{s})$ and the cylinder-cancer clearance $\left(C_{1}\right)$ of $12.5 / 5.5 \mathrm{~mm}$, was found to be as the developed rotor 7 teeth (30.186 kw.h/fed.), the developed rotor 10 teeth (34.600 $\mathrm{kw} . \mathrm{h} / \mathrm{fed}$.), the developed rotor 15 teeth $(41.159 \mathrm{kw} . \mathrm{h} / \mathrm{fed}$.$) and the$ original rotor 15 teeth (51.613 kw.h/fed.).

7- The least values of the operating costs at the feed rate of $2000 \mathrm{~kg} / \mathrm{h}$, operating forward speed of $1.22 \mathrm{~km} / \mathrm{h} / \mathrm{g}$ rain moisture content of $21 \%$, threshing drum speed of $500 \mathrm{rpm}(17 \mathrm{~m} / \mathrm{s})$ and the cylinder. Concave clearance $\left(c_{1}\right)$ of $12.5 / 5.5 \mathrm{~mm}$, was found to be as the developed rotor 7 teeth $(223.50 \mathrm{LE} / \mathrm{fed}$.), the developed rotor 10 teeth $(240.50$ 
LE/fed.), the developed rotor 15 teeth $(270.25$ LE/Fed.) and the original rotor 15 teeth (314.75 LE/fed.).

8- The better results were reached under operating conditions was found to be as threshing drum speed of $500 \mathrm{rpm}$, feed rate of 2000 $\mathrm{kg} / \mathrm{h}$, operating forward speed of $1.22 \mathrm{~km} / \mathrm{h}$, cylinder-concave clearance of $C,(12.5 / 5.5 \mathrm{~mm})$ at grain moisture content of $21 \%$ was found to be as the developed rotor ( 7 teeth), whereas the total grain losses of $1.68 \%$, required energy of $30.186 \mathrm{kw} . \mathrm{h} / \mathrm{fed}$., operating costs of $223.50 \mathrm{LE}$, fed., threshing efficiency of $99.34 \%$, separation efficiency of $99.27 \%$ and, cleaning efficiency of $99.71 \%$.

\section{INTRODUCTION}

ecently, strengthen support for take advantages of the modern
bio-technology would be of paramount importance for Egypt to
attain self-sufficiency of rice crop. Rice crop is one of the major field crops in Egypt. It is grown in 1.3 million feddan of the total agricultural area. During the five years before 2000 paddy production averaged 4.6 million tons and the national average yield was 3.6 tons/fed., Ministry of Agriculture (2000).

Mechanical harvesting is one of the most important operations in rice crop production. Government encourages the farmers to use new technology to overcome the high cost of traditional harvesting and labour shortage especially in the harvesting time. Therefore it is necessary to mechanize rice harvesting to reduce losses and costs. Combine harvester should be used for its minimum production losses and low cost.

Kepner et al., (1982) found that seed losses from a combine can occur in connection with any of the four basic operations. Theses losses are often indentified as header, cylinder, walker and shoe losses. Gathering losses in direct combining include heads, pods or ears and free seed, lost during the cutting and conveying operations. They stated that threshing effectiveness is related to: cylinder speed, cylinder concave clearance, number of rows concave teeth used with spike tooth cylinder type of crop, the condition of crop in terms of moisture content, maturity etc., and the rate at which the material is fed into the madnine.

Sheruddin et al., (1991) found that with decreasing moisture content of grain, increased grain losses. The lowest grain losses were observed at a 
range of 4-15 (w.b.) grain losses increased with dalay in harvesting and at different timings of harvest.

Abd El-Mawla (1996) stated that combine harvesters have been developed to increase the combine capacity in combining certain crops, to overcome hard conditions of the crops, to facilitate easier maintenance and to increase the overall efficiency of the combine.

Ichikawa and Sugiyama (1986) developed a new combine harvester equipped with screw type threshing and separating mechanisms. They found that the harvesting performance of the new combine showed the total grain loss rate was lower than $3 \%$ and the percentage of damaged grains was less than $1 \%$ for rice, soybean, wheat and barley crops.

Kamel (1999) evaluated the total rice grain harvesting losses utilizing two different combine harvesters (CA-385, $1.4 \mathrm{~m}$, hold. In and CA-760, $2.06 \mathrm{~m}$, through-in) with three harvesting speeds of $0.3,0.5$ and $0.8 \mathrm{~m} / \mathrm{s}$ for both combines and three rice varieties of (Giza 178, Sakha 101 and Sakha 102). The results indicated that the total losses of grain was 3.3, 2.4 and 2.8\% for rice varieties Giza 178, Sakha 101 and Sakha 102 respectively for combine harvester CA-385 in comparison with 3.9, 3.1 and $3.4 \%$ for combine harvester CA-760.

El-Awady et al., (2000) evaluate the performance of Barmel ricethresher. They concluded that the best performance of Barmel rice thresher was at $550 \mathrm{rpm}(29.64 \mathrm{~m} / \mathrm{s})$ which gave minimum criterion cost of $4.13 \mathrm{LE} /$ ton, acceptable cleaning efficiency of $94.61 \%$ and threshing capacity of $2.68 \mathrm{ton} / \mathrm{h}$.

Morad and Fouda (2003) develop long axial flow rice thresher (Barmel thresher) to be suitable for threshing rice crop with high efficiency and low power consumption. Increasing input capacity from 1.8 to 2.5 ton/h, at constant drum speed of $24.64 \mathrm{~m} / \mathrm{s}$, increasing threshing power by 14.12 and $11.69 \%$ for threshers before and after development, resp. Also, increasing drum speed from 21.51 to $26.70 \mathrm{~m} / \mathrm{s}$, at constant input capacity of 2.25 ton/h, increased threshing power by 14.12 and $11.69 \%$ for threshers before and after development, resp.

El-Hadad (2000) stated that the threshing efficiency increased with increasing drum speed and decreasing feed rate. The maximum threshing efficiency was $99.76 \%$ at drum speed of $21.25 \mathrm{~m} / \mathrm{s}$ (1400 rpm), and feed 
rate of $15 \mathrm{~kg} / \mathrm{min}$. (900 kg/h). The maximum amount of visible grain damage was $0.90 \%$ under these conditions.

Simonyan and Oni (2001) reported that there is an increase in threshing efficiency and extractor efficiency with decrease by the cylinder speed.

El-Nakib et al. (2003) stated that an evaluation was carried out using Kubota combine (Pro 481) as a mechanical harvester of rice (Sakha 102). The grain moisture content was varied at (23.8, 19.3 and 16.5\%). Forward speed were $(2.3,2.7,4.5$ and $5.14 \mathrm{~km} / \mathrm{h})$ and air fan velocities (22.2, 25.3 and 27.6). The were previous factors studied and evaluated o combine losses (as header, threshing, separating and shoe losses). The results show that:

- Header, threshing, separating and shoe losses increase with increasing of the forward speed and the decrease of grain moisture content.

- The total losses (TL), forward speed (S) and grain moisture content (GMC) were formulated by the formula "TL= $\left(10.5 \mathrm{GMC}^{-0.79}\right) \mathrm{S}^{0.75}$, under previously mentioned condition.

- The optimum operating harvesting rice crop was at combine forward speed $4.5 \mathrm{~km} / \mathrm{h}$ and grain moisture content of $16.5 \%$.

- The optimum air fan velocity during operating rice was $6.17 \mathrm{~m} / \mathrm{s}$. The aim of this research is to develop the axial-flow threshing and separating drum to improve the straw flow to reduce the problems of the blockage, losses and top improve field capacity and grain yield. Consequently, minimizing both grain losses and operational costs.

\section{MATERIAL AND METHODS:}

From the interview with some operators of the combine machine, they noticed that many difficulties to achieve smooth operation in fields specifically for the wheat and rice crops. The most frequent breakdowns occurred because of crop and straw blockage inside the threshing separation housing. The drum blockage occurred frequently causing low machine productivity of field efficiency, low through put and high of total grain losses, in this study it proposed the vane rotors with an inclined angle in the direction of rotation. So, improvements were added to the axial-flow threshing/separating drum to increase the straw flow 
and discharge through out to reduce blockage and overcome the complain of the increasing of the total grain losses and to improve machine productivity and field efficiency.

The main experiments were carried out at Ahmed Ramie Farm, Etai Al Barod, El-Behera Governorate,t o compare different types of threshing and separation drums of combine class crop Tiger, Table (1).

The experiments were conducted in a productive rice crop grown with the variety (Giza 171) in an area of about 4.10 feddans.

Table (1): Specifications of Class crop tiger combine.

\begin{tabular}{|c|c|c|}
\hline No. & Feature & Class crop tiger combine \\
\hline 1 & Source of manufacture & Germany \\
\hline 2 & Model & Crop tiger \\
\hline 3 & Type & Standard \\
\hline 4 & Engine & 4-cylinder diesel engine (Isuzu) \\
\hline 5 & Engine power: & $\begin{array}{l}\text { Powerful } 43 \mathrm{~kW}(58 \mathrm{hp}) \text { at } 3000 \\
\text { r.p.m. }\end{array}$ \\
\hline 6 & Drive & Hydrostatic $0-10 \mathrm{~km} / \mathrm{h}$ \\
\hline 7 & Undercarriage & Rubber wheel type \\
\hline 8 & $\begin{array}{l}\text { Dimensions: } \\
\text { - Length with cutter bar } \\
\text { - Width with cutter bar } \\
\text { - high (without sunroof) } \\
\text { - net weight }\end{array}$ & $\begin{array}{ll}560 & \mathrm{~cm} \\
255 & \mathrm{~cm} \\
298 & \mathrm{~cm} \\
3600 & \mathrm{~kg}\end{array}$ \\
\hline 9 & Cutter bar: & $\begin{array}{l}2.1 \text { m cutting width. } \\
5 \text {-section reel with } 2 \text { stage drives for } \\
18 \text { and } 31 \mathrm{rpm} \text {. } \\
\text { Hydraulic cutting height control. }\end{array}$ \\
\hline 10 & $\begin{array}{l}\text { Threshing system: } \\
\text { - length rotor } \\
\text { - diameter rotor } \\
\text { - } 4 \text { speeds, }\end{array}$ & $\begin{array}{l}\text { Threshing and separating } \\
1800 \mathrm{~mm} . \\
450 \mathrm{~mm} . \\
500,803,1013 \text { and } 1280 \mathrm{rpm} .\end{array}$ \\
\hline 11 & $\begin{array}{l}\text { Threshing section width: } \\
\text { Separating section width }\end{array}$ & $\begin{array}{l}575 \mathrm{~mm} . \\
1225 \mathrm{~mm}\end{array}$ \\
\hline 12 & Grain tank & $\begin{array}{l}1200 \text { liter capacity } \\
\text { Top filling system } \\
\text { Swinging unloading auger }\end{array}$ \\
\hline
\end{tabular}


The basic developments of the rotor ledge are as follows:

1- Design and fabricate three serrated agitator ledge (15, 10, 7 teeth), so that the passing crop and separation will easy. The designed serrated agitator ledges are shown in Fig. (1), with an inclined angle in the direction of rotation.

2- The length of separation to be $110.5 \mathrm{~cm}$ instead of $90.5 \mathrm{~cm}$ increases the grain separation efficiency.

3- The thickness of the separation vane to be $5 \mathrm{~mm}$ instead of $3.5 \mathrm{~mm}$ and (using steel 60) to, overcome the wear of vanes during the separation operation.

4- Installation a set of louvers inside the rotor's cover, with change the angle of the louvers to be $75^{\circ}$ rather than $90^{\circ}$ along the axis of the threshing and separation cylinder.

5- Adjusting the cylinder concave clearance by using three levels of clearance namely 12.5/5., 13/6 and 16/7 mm for the rice, Fig. (2)>

6- Sing two levels of feeding rate: 2000 and $3000 \mathrm{~kg} / \mathrm{h}$ at forward speeds 1.22 and $1.91 \mathrm{~km} / \mathrm{h}$.

7- Three levels of cylinder speed as 11.77 (500), 14.80 (630) and 18.91 (803) $\mathrm{m} / \mathrm{s}$ (r.p.m.).

8- The developed parts wre made mainly from local steel sheet. The following steps of manufacture processing for serrated agitator ledge were carried out:

1- Cutting up; 2- Rasping; 3- Rolling process; 4- Heat treatment; 5Milling. To meet high or repeated loads (impact loads).

\section{1- Threshing drums:}

\subsection{The original drum:}

Fig. (3) show the original drum which is $180 \mathrm{~cm}$ in length with $45 \mathrm{~cm}$ diameter used rice crop. The rotor shaft passes through the center of the cylindrical rotor where a circular steel sheet is welded to close each of the rotor ends. Bases are welded on the rotor surface to fix the threshing elements and separation parts in their positions respectively.

\section{a) Threshing part:}

The threshing section length is $57.5 \mathrm{~cm}$ and consists of 8 bars spike0tooth fixed on the drum surface in rice crop. The concave, is formed from rectangular (Oval halls) bars parallel to the cylinder axis. The clearance between the concave bars and the corrugated cylinder bars is adjustable. No changes were done to the section assigned for threshing. 


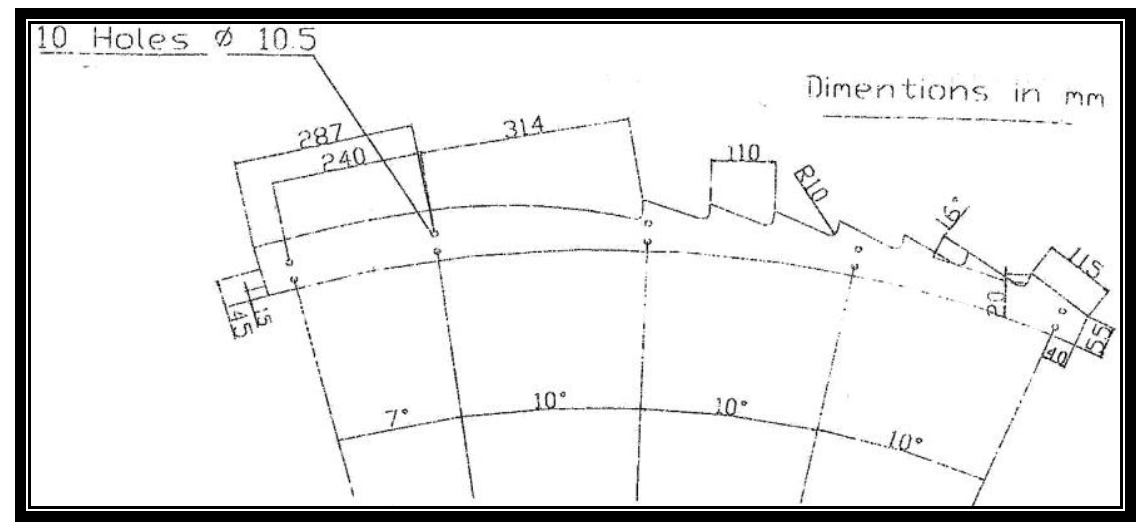

(A) 7 teeth

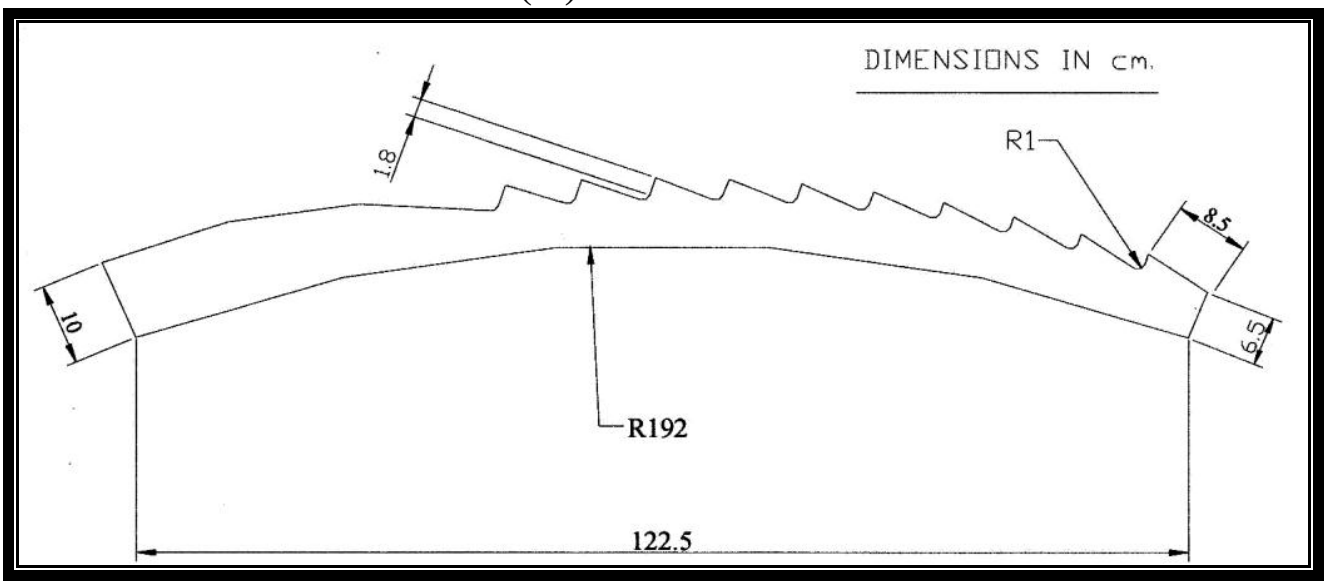

(B): 10 teeth.

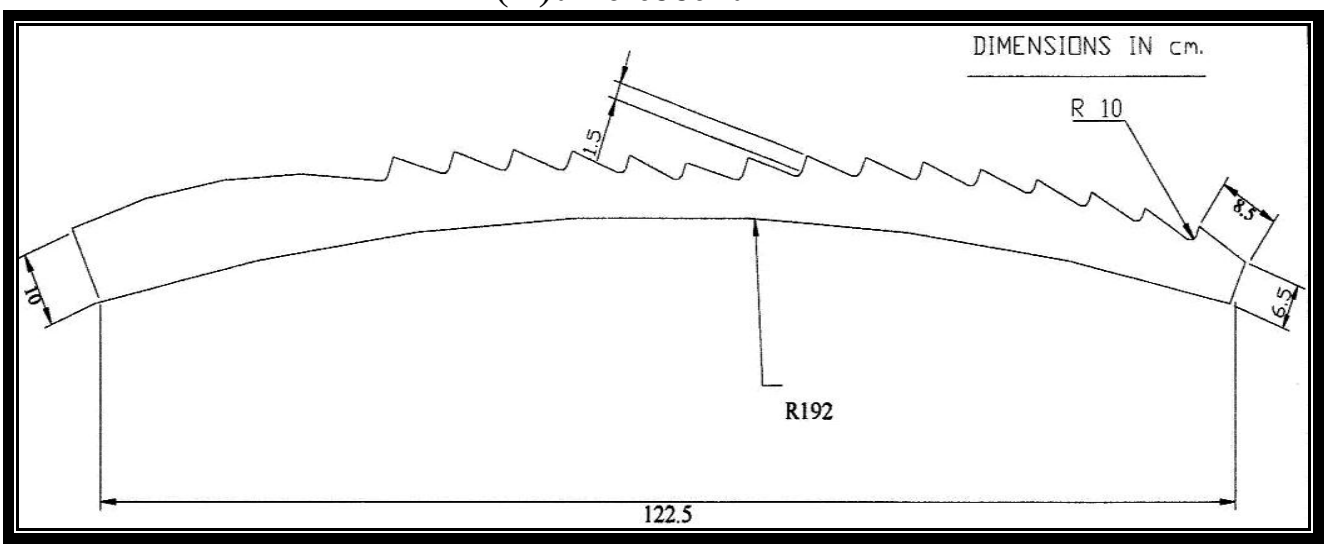

(C): 15 teeth

Fig. (1): Design of the serrated agitator ledges for the section of separation 


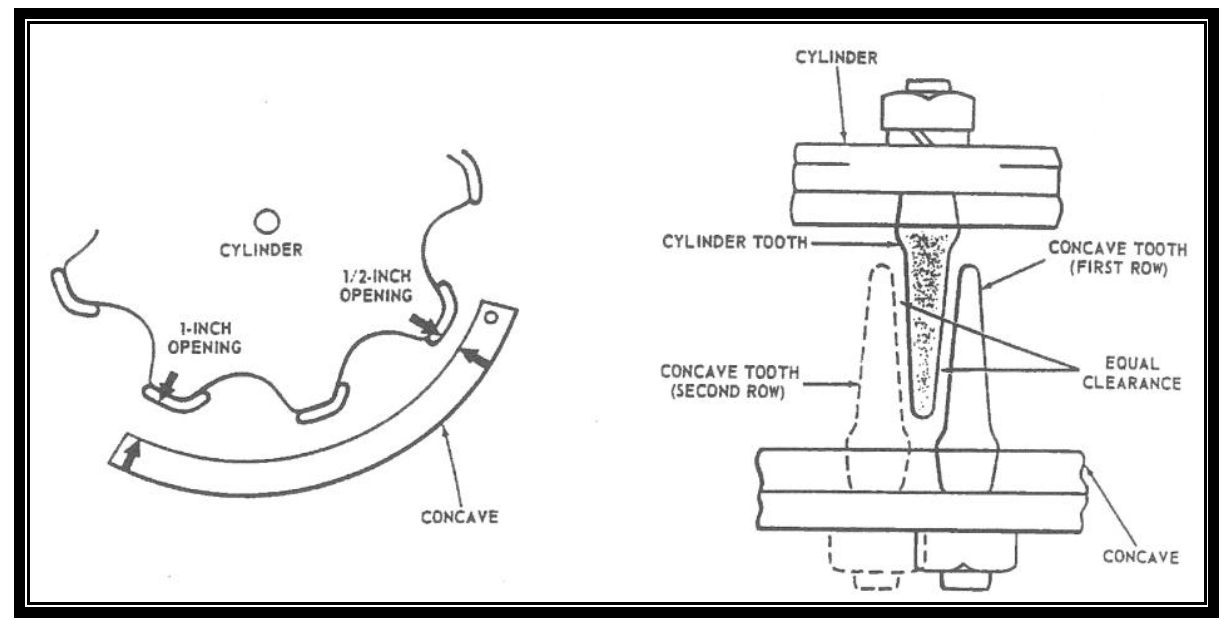

Chart 1: Typical front and rear spacing Proportions for wheat crop.

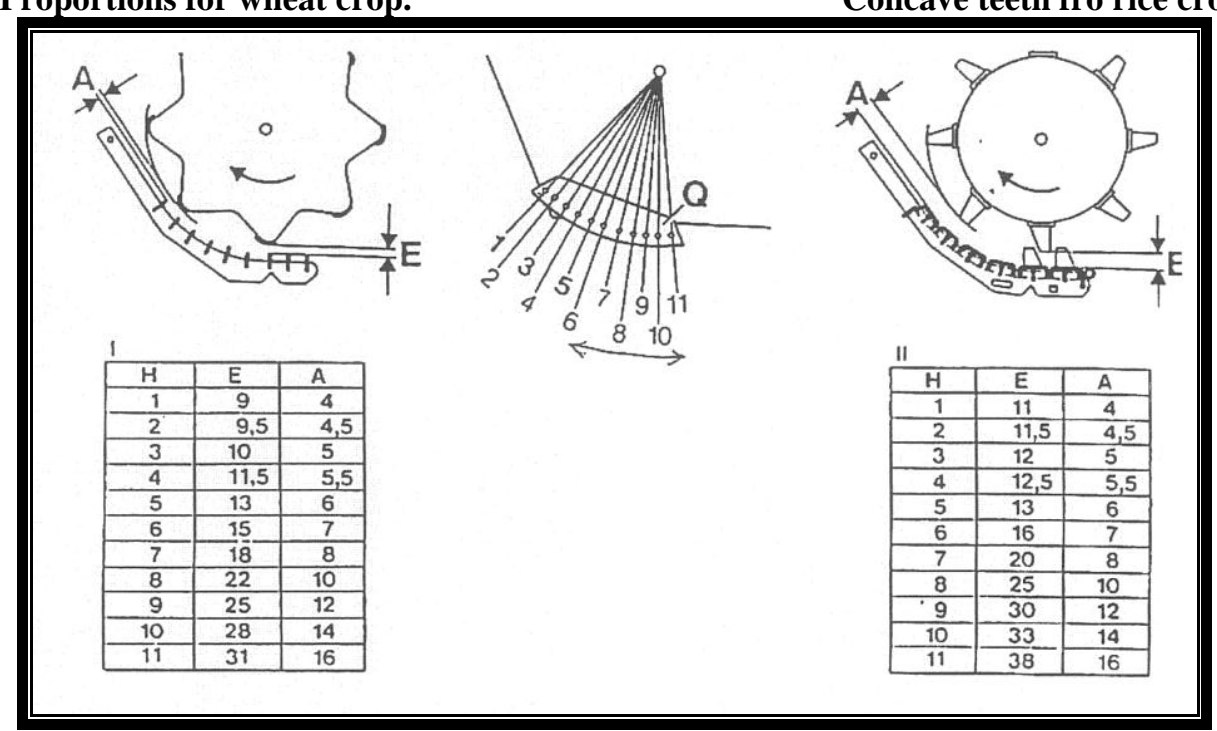

Fig. (2): Drum concave-clearance:

Chart I: Concave settings for threshing rice, by spike tooth drum and spike concave

Chart II: Concave settings for threshing wheat, by rasp bar.

$\mathrm{H}$ - Levering. Hole in quadrant,

$\mathrm{E}=$ Entrance of concave $(\mathrm{mm})$.

$\mathrm{A}=$ Exit of concave $(\mathrm{mm})$;

$\mathrm{Q}=$ The front and rear of the concave are simultaneously adjusted.

\section{b) Separation part:}

The serrated agitator ledge (vane rotors) assigned for separation section with length $90.5 \mathrm{~mm}$ is fixed on the body of rotor. It has two ends, the 
height of $1^{\text {st }}$ end is $10 \mathrm{~cm}$ at the straw rejecting part and $7.5 \mathrm{~cm}$ at the other end. Four serrated agitator bars which are fixed to the above mentioned bases parallel to the drum axial. The thickness of the separation vane is $3.5 \mathrm{~mm}$. The number of teeth on the serrated agitator bar is 15 teeth.

\section{c) Straw exit section:}

It is the rear end of the separation agitator ledge section, the height 10 $\mathrm{cm}$, length $32 \mathrm{~cm}$ and it is not serrated to work as a discharge edge in front of straw exit section outer. The straw is discharged on the left-hand side into the ground.

\section{d) Louvers inside the threshing drum:}

Installation of a set of louvers inside the threshing rotor's cover, such that could be set at $90^{\circ}$ degrees to the drum axis of the threshing the separation cylinder.

\subsection{The developed drum:}

Fig. (4) show the developed vane rotors which is $122.5 \mathrm{~cm}$ length with 45 cm diameter.

\section{a) Separation section:}

The serrated agitator ledge (vane rotors) assigned for separation section with length $1005 \mathrm{~mm}$ is fixed on the body of rotor. It has two ends, the height of $1^{\text {st }}$ end is $10 \mathrm{~cm}$ at the straw rejecting part and $7.5 \mathrm{~cm}$ at the other end. Four serrated agitator bars which are fixed to inclined angle in the direction of rotation to the drum axial. The thickness of the separation wing is $5 \mathrm{~mm}$. The number of teeth on the serrated agitator bar is 15,10 and 7 teeth of four serrated agitator bars (vane rotors) using.

\section{b) Straw rejected outlet:}

This part works as beater with four vanes. Each modified with dimensions of the rear of the separation agitator section height $10 \mathrm{~cm}$ and length $22 \mathrm{~cm}$ is not serrated to work as a discharge edge in front of straw discharge outlet. The kernels separated here fall also into the front and rear conveying auger through. The straw is discharged on the left-hand side into the ground or is delivered via conveyor belt the rear of the combine.

\section{c) Louvers inside the threshing drum:}

The direction of louvers with horizontal axes $75^{\circ}$ degrees and vertical axes $15^{\circ}$ degrees tot eh drum axis of the threshing and separation cylinder, with rice crop. Installation of a set $f$ louvers inside the threshing drum's cover. Table (2) show a comparison between the original and developed drums. 
1-Shaft

2-8 spike tooth bars,

3-Drum blades through in,

4-4 serrated agitator bars,

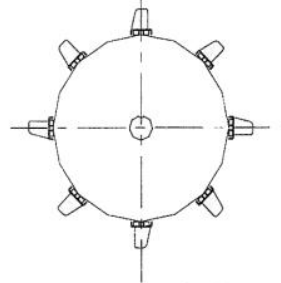

Side view in the front

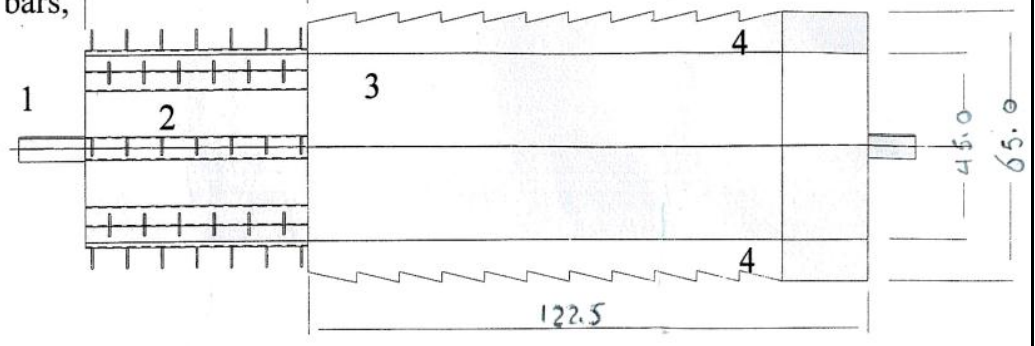

Fig. (3): The original drum with $180 \mathrm{~cm}$ length and $45 \mathrm{~cm}$ diameter used or the rice crop.

1-Shaft

2-8 spike tooth bars,

3-Drum blades through in,

4-4 serrated agitator bars,
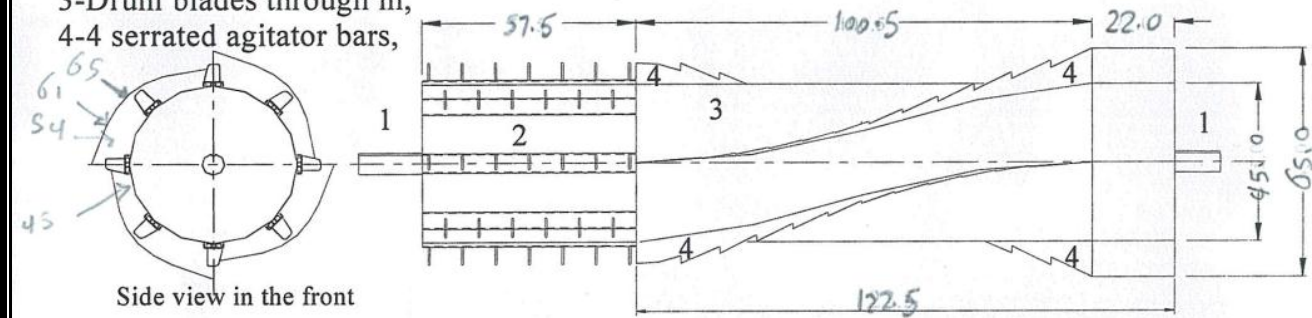

Fig. (4): The developed serrated agitator ledge (vane rotors) for rice crop.

1-Shaft

2-8 spike tooth bars,

Dimentions in $\mathrm{cm}$

3-Drum blades through in, Shreshing unit

4-4 serrated agitator bars,

Separation unit Discharge unit

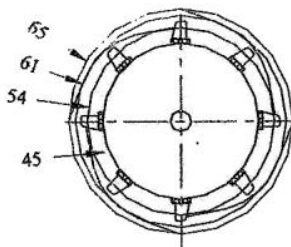

Side view in the front

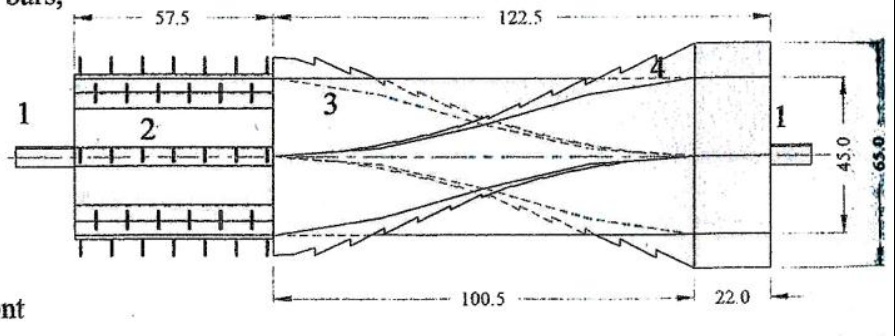

(B) Front view

Fig. (5): Developed drum shows different diameter and pathway the vane rotors on the cylinder. 


\section{The vane rotors preparation:}

\section{A) Vane rotors shape:}

Vane rotors shape shown in Fig. (5).

Table (2): Technical data of two different drum (developed drum and original drum) for rice crop.

\begin{tabular}{|l|c|c|}
\hline \multicolumn{1}{|c|}{ Items } & Original drums & Developed drums \\
\hline Diameter the drum, cm & 180 & 180 \\
\hline Separating section: length, cm & 90.5 & 110.5 \\
\hline $\begin{array}{l}\text { Height the serrated agitator } \\
\text { bare, mm }\end{array}$ & 10 & 8 \\
\hline $\begin{array}{l}\text { Number of tip on the serrated } \\
\text { agitator bare }\end{array}$ & 15 & 15,10 and 7 \\
\hline $\begin{array}{l}\text { Length of the separated } \\
\text { agitator bars, cm }\end{array}$ & 90 & 1.5 \\
\hline $\begin{array}{l}\text { The tip depth of the separated } \\
\text { agitator bars, cm }\end{array}$ & 2.5 & 5 \\
\hline $\begin{array}{l}\text { Thickness of the separated } \\
\text { agitator bars, mm }\end{array}$ & 2 & 2.5 \\
\hline Weight of the drum, kg & 2 & 10 \\
\hline
\end{tabular}

\section{Performance parameters for threshing cylinder:}

The following criteria by FAO (1994) were used to evaluate the performance of the threshing machine on threshing efficiency, grain quality and cleaning efficiency:

Unthreshed grain:

Unthreshed grain $\%=\frac{\text { Weight of unthreshed grain }}{\text { Weight of total grain }} \times 100$.

\section{Threshing efficiency:}

Threshing efficiency $\%=(100-$ unthreshed grain \% $)$

\section{Grain damage:}

$$
\text { Grain damage } \%=\frac{\text { Weight of grain damage }}{\text { Weight of total grain }} \times 100 .
$$

\section{Grain quality:}

Grain quality $\%=[100-$ grain damage (visible) \% $]$ 


\section{Cleaning losses:}

Cleaning losses \%

Weight of cleaning losses

Weight of total grain

x 100

\section{Cleaning efficiency:}

Cleaning efficiency $\%=[100-$ cleaning losses \% $]$

\section{Total losses:}

Total losses $\%=$ [Grain damage + Unthreshed grain + Cleaning losses $] \ldots .$. (7)

\section{Theoretical field capacity:}

The theoretical field capacity (TFC) was calculated by using the following formula (Kepner et al., 1982).

$$
\mathrm{TFC}=\frac{\mathrm{W} \times \mathrm{S}}{4.2}
$$

Where:

$\mathrm{W}$ is the working width of a machine, $\mathrm{m}$;

$\mathrm{S}$-average machine forward speed, $\mathrm{km} / \mathrm{h}$.

\section{Actual field capacity:}

The actual field capacity (AFC) was calculated by using the following formula (Kepner et al. 1982).

$$
\mathrm{AFC}=\frac{60}{\mathrm{TU}+\mathrm{TL}} \quad \ldots . . \mathrm{fed} . / \mathrm{h} . . . . .(9)
$$

Where:

TU is the utilization time per feddan in minutes;

$\mathrm{TL}$ - Summation of lost time per feddan in minutes.

\section{Field of efficiency:}

The field efficiency $\left(\eta_{\mathrm{f}}\right)$ was calculated by using the following formula (Kepner et al. 1982).

$$
\eta_{\mathrm{f}}=\frac{\mathrm{AFC}}{\mathrm{TFC}} \quad \mathrm{X} 100, \ldots
$$

\section{Power required:}

To estimate the engine power during harvesting process, the decrease in fuel level was accurately measured immediately after each treatment. The following formula was used to estimate the power required (PR), Hunt 1983. 


$$
\begin{aligned}
& \mathrm{PR}=\mathrm{FC} \times \frac{1}{3600} \quad \text { Pf } \mathrm{x} \text { L.C.V. } \mathrm{x} 427 \mathrm{x} \eta_{\mathrm{th}} \mathrm{x} \eta_{\mathrm{m}} \mathrm{x} \quad \frac{1}{75} \times 0.746 \\
& =3.209 \text {, } \\
& \mathrm{kw}
\end{aligned}
$$

where:

$\mathrm{FC}$ is the fuel consumption, $\mathrm{L} / \mathrm{h}$.

$P f$. Density of the fuel, $\mathrm{kg} / \mathrm{L}$ (for Diesel $=0.85$ ).

L.C.V. = Lower calorific value of fuel, $\mathrm{Kcal} / \mathrm{Kg}$ (average of solar $=10000(\mathrm{Cal} / \mathrm{Kg})$;

427 - constant (thermo-mechanical equivalent), (kg.m/Kcal);

$\eta_{\mathrm{m}}=$ Mechanical efficiency for the engine (considered to be about $80 \%$ for diesel engine);

0.746- coefficient for changing from hp to $\mathrm{kw}$;

\section{Energy requirement:}

The energy requirement was calculated by using the following formula:

$$
\text { Energy requirements } \frac{\mathrm{PR}(\mathrm{kW})}{\mathrm{AFC}(\mathrm{fed} . / \mathrm{h})} \mathrm{kW} . \mathrm{h} / \mathrm{fed}
$$

\section{Cost analysis:}

Machine cost was determined using the following equation (Awady et al. 1982):

$$
\left.\mathrm{C}=\frac{\mathrm{p}}{\mathrm{ht}}\left(\frac{1}{\mathrm{a}}+\frac{1}{2}+t+r\right)+(0.9 \text { w.s.f. })\right)+\frac{\mathrm{m}}{144} \ldots \ldots \ldots . . \mathrm{LE} / \mathrm{h}
$$

Where:

$\mathrm{c}$ is the hourly cost, $\mathrm{LE} / \mathrm{h}$;

$\mathrm{p}$ - Price of machine, LE;

$\mathrm{h}$ - yearly working hours, h/year;

a- life expectancy of the machine, $h$

i- interest rate/year;

t- taxes, over heads ratio;

$\mathrm{r}$ - repairs and maintenance ratio;

0.9 - factor accounting for lubrications;

$\mathrm{w}$ - engine power, hp 
s - specific fuel consumption, L/hp.h;

f- fuel price, LE/L;

$\mathrm{m}$ - monthly average wage, LE;

144 - reasonable estimation of monthly working hours.

The operational cost was determined using the following equation:

Machine cost (LE/h)

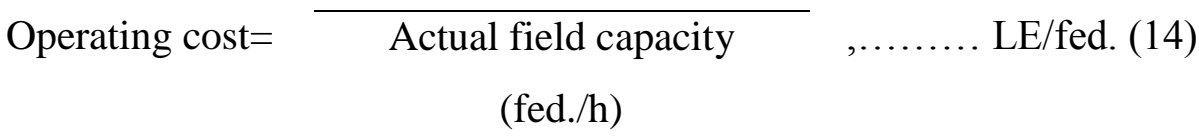

\section{RESULTS AND DISCUSSION}

The main objective of present study is to develop the axial-flow threshing, separation drum to improve the straw flow to reduce the problems of blockage, losses and to improve field capacity and grain yield. Consequently, minimizing both grain losses and operational costs. The experiments were carried out to compare four different threshing and separation drums: original vane rotors (15 teeth), developed vane rotors (15 teeth), developed vane rotors (10 teeth) and developed vane rotors (7 teeth) during harvesting rice crop variety (Giza 171).

The cylinder-concave clearance was adjusted to obtain three clearances for rice crop. The cylinder-concave clearances for the four threshing and separation drums of the combine (class crop tiger) were $\mathrm{C}_{1}(12.5 / 5.5), \mathrm{C}_{2}$ (13/6) and $\mathrm{C}_{3}(16 / 7) \mathrm{mm}$.

\section{Effect of some operating parameters on grain losses:}

The threshing losses are affected directly by different operating parameters such as threshing drum speed, feed rate, operating forward speed, grain moisture content.....etc.

\section{a- Unthreshed grain:}

Generally, the unthreshed grain increased by increasing both feed rate and operating forward speed, and the unthreshed grain decreased by increasing threshing drum speed, decreasing the cylinder concave clearance. Data in Table (3) show that increasing feed rate from 2000 to $3000 \mathrm{~kg} / \mathrm{h}$ at drum speed of $803 \mathrm{rpm}$, increased unthreshed grain from 2.07 to $2.29 \%$ at grain moisture content $21 \%$. The increase in the 
Table (3): Effect of cylinder-concave clearance on unthreshed grain (\%) at three cylinder speeds and two feed rates for rice crop (Giza 171) at moisture content $21 \%$.

\begin{tabular}{|c|c|c|c|c|c|c|c|c|c|c|c|c|}
\hline \multirow{4}{*}{$\begin{array}{c}\text { Cylinder } \\
\text { speed, r.p.m. }\end{array}$} & \multicolumn{12}{|c|}{ Unthreshing grain, $\%$} \\
\hline & \multicolumn{3}{|c|}{ Original rotor (15 teeth) } & \multicolumn{3}{|c|}{ Developed rotor (15 teeth) } & \multicolumn{3}{|c|}{ Developed rotor (10 teeth) } & \multicolumn{3}{|c|}{ Developed rotor ( 7 teeth) } \\
\hline & \multicolumn{12}{|c|}{ Feed rate $=2000 \mathrm{~kg} / \mathrm{h}$ at forward speed $=1.22 \mathrm{~km} / \mathrm{h}$} \\
\hline & $\mathrm{C} 1$ & $\mathrm{C} 2$ & $\mathrm{C} 3$ & $\mathrm{C} 1$ & $\mathrm{C} 2$ & $\mathrm{C} 3$ & $\mathrm{C} 1$ & $\mathrm{C} 2$ & $\mathrm{C} 3$ & $\mathrm{C} 1$ & $\mathrm{C} 2$ & $\mathrm{C} 3$ \\
\hline 500 & 2.25 & 2.51 & 2.76 & 0.89 & 1.16 & 1.31 & 0.79 & 0.92 & 1.16 & 0.66 & 0.83 & 1.01 \\
\hline 630 & 2.19 & 2.43 & 2.70 & 0.71 & 0.96 & 1.25 & 0.65 & 0.84 & 1.09 & 0.54 & 0.73 & 0.95 \\
\hline 803 & 2.07 & 2.33 & 2.58 & 0.66 & 0.84 & 1.11 & 0.54 & 0.78 & 0.91 & 0.42 & 0.66 & 0.88 \\
\hline \multirow{2}{*}{$\begin{array}{c}\text { Cylinder } \\
\text { speed, r.p.m. }\end{array}$} & \multicolumn{12}{|c|}{ Feed rate $=3000 \mathrm{~kg} / \mathrm{h}$ ar forward speed $=1.91 \mathrm{~km} / \mathrm{h}$. } \\
\hline & $\mathrm{C} 1$ & $\mathrm{C} 2$ & $\mathrm{C} 3$ & $\mathrm{C} 1$ & $\mathrm{C} 2$ & $\mathrm{C} 3$ & $\mathrm{C} 1$ & $\mathrm{C} 2$ & $\mathrm{C} 3$ & $\mathrm{C} 1$ & $\mathrm{C} 2$ & $\mathrm{C} 3$ \\
\hline 500 & 2.46 & 2.75 & 2.91 & 1.15 & 1.34 & 1.56 & 0.91 & 1.14 & 1.35 & 0.80 & 1.03 & 1.21 \\
\hline 630 & 2.41 & 2.66 & 2.85 & 0.94 & 1.17 & 1.38 & 0.82 & 1.06 & 1.23 & 0.72 & 0.95 & 1.16 \\
\hline 803 & 2.29 & 2.55 & 2.73 & 0.82 & 1.07 & 1.29 & 0.76 & 0.93 & 1.10 & 0.62 & 0.86 & 1.08 \\
\hline
\end{tabular}

* The cylinder-concave clearances of the combine were C1 (12.5/5.5), C2 (13/6) and C3 (16/7) mm front/rear for rice crop. 
percentage of unthreshed grain by increasing feeding rate is attributed to the density (excessive) plants in the threshing chamber, plants leave the device without complete threshing that tends to increase unthreshed grain. Increasing drum speed from 500 to $803 \mathrm{rpm}$ at feed rate of 2000 $\mathrm{kg} / \mathrm{h}$, decreased the unthreshed grain from 2.25 to $2.07 \%$ at grain moisture content $21 \%$.

Thus, the sequence of the cylinder-concave clearance to the least values of unthreshed grain was found to be as the following order: $\mathrm{C}_{1}(12.5 / 5.5)$, $\mathrm{C}_{2}(13 / 6)$ and $\mathrm{C}_{3}(16 / 7) \mathrm{mm}$ at grain moisture content $21 \%$, feed rate $2000 \mathrm{~kg} / \mathrm{h}$ and drum speed $803 \mathrm{rpm}$.

Also, the sequence of the four different threshing and separation drums to the least percentage value of unthreshed grain was found to be as the following order; developed vane rotors ( 7 teeth), developed vane rotors (7 teeth), developed vane rotors (10 teeth), developed vane rotors (15 teeth) and original vane rotors (15 teeth).

\section{b- Grain damage:}

Generally, the grain damage increased by increasing both feed rate operating forward speed and threshing drum speed, and the grain damage decreased by increasing the cylinder concave clearance. Clearance. Data in Fig. (7) show that increasing feed rate from 2000 to $3000 \mathrm{~kg} / \mathrm{h}$ at drum speed of $803 \mathrm{rpm}$, increased grain damage from 2.75 to $2.98 \%$ at grain moisture content $21 \%$. The increase in the percentage of grain damage by increasing feed rate is attributed to the excessive plants in the threshing chamber, so the capsules leave the device without complete threshing that tends to increase un-separated grain. The increase in the percentage of separation losses by increasing drum speed was attributed to the high stripping and impacting forces applied to the plants.

Thus, the sequence of the cylinder. Concave clearance to the least values of grain damage percentage was found to be as the following order: $\mathrm{C}_{3}$ (16/7), $\mathrm{C}_{2}(13 / 6)$ and $\mathrm{C}_{1}(12.5 / 5.5) \mathrm{mm}$ at grain moisture content $21 \%$, feed rate $2000 \mathrm{~kg} / \mathrm{h}$ and drum speed $803 \mathrm{rpm}$. Also, the sequence of the four different threshing and separation drums to the least percentage values of grain damage was found to be as the following order developed vane rotors (7 teeth), developed vane rotors (10 teeth), developed vane rotors (15 teeth) and original vane rotors (15 teeth). 
Table (4): Effect of cylinder-concave clearance on grain damage (visible) (\%) at three cylinder speeds and two feed rates for rice crop (Giza 171) at moisture content 21\%).

\begin{tabular}{|c|c|c|c|c|c|c|c|c|c|c|c|c|}
\hline \multirow{4}{*}{$\begin{array}{c}\text { Cylinder } \\
\text { speed, r.p.m. }\end{array}$} & \multicolumn{12}{|c|}{ Unthreshing grain, $\%$} \\
\hline & \multicolumn{3}{|c|}{ Original rotor (15 teeth) } & \multicolumn{3}{|c|}{ Developed rotor (15 teeth) } & \multicolumn{3}{|c|}{ Developed rotor (10 teeth) } & \multicolumn{3}{|c|}{ Developed rotor (7 teeth) } \\
\hline & \multicolumn{12}{|c|}{ Feed rate $=2000 \mathrm{~kg} / \mathrm{h}$ at forward speed $=1.22 \mathrm{~km} / \mathrm{h}$} \\
\hline & $\mathrm{C} 1$ & $\mathrm{C} 2$ & $\mathrm{C} 3$ & $\mathrm{C} 1$ & $\mathrm{C} 2$ & $\mathrm{C} 3$ & $\mathrm{C} 1$ & $\mathrm{C} 2$ & $\mathrm{C} 3$ & $\mathrm{C} 1$ & $\mathrm{C} 2$ & $\mathrm{C} 3$ \\
\hline 500 & 2.31 & 2.07 & 1.89 & 1.13 & 0.93 & 0.76 & 0.95 & 0.81 & 0.68 & 0.73 & 0.61 & 0.55 \\
\hline 630 & 2.53 & 2.32 & 2.18 & 1.45 & 1.24 & 0.98 & 1.28 & 1.13 & 0.92 & 0.96 & 0.84 & 0.77 \\
\hline 803 & 2.75 & 2.56 & 2.39 & 1.74 & 1.56 & 1.31 & 1.59 & 1.44 & 1.36 & 1.13 & 1.07 & 0.91 \\
\hline \multirow{2}{*}{$\begin{array}{c}\text { Cylinder } \\
\text { speed, r.p.m. }\end{array}$} & \multicolumn{12}{|c|}{ Feed rate $=3000 \mathrm{~kg} / \mathrm{h}$ ar forward speed $=1.91 \mathrm{~km} / \mathrm{h}$} \\
\hline & $\mathrm{C} 1$ & $\mathrm{C} 2$ & $\mathrm{C} 3$ & $\mathrm{C} 1$ & $\mathrm{C} 2$ & $\mathrm{C} 3$ & $\mathrm{C} 1$ & $\mathrm{C} 2$ & $\mathrm{C} 3$ & $\mathrm{C} 1$ & $\mathrm{C} 2$ & $\mathrm{C} 3$ \\
\hline 500 & 2.52 & 2.29 & 2.12 & 1.43 & 1.24 & 1.02 & 1.14 & 1.04 & 0.93 & 0.93 & 0.86 & 0.76 \\
\hline 630 & 2.74 & 2.64 & 2.39 & 1.73 & 1.56 & 1.35 & 1.30 & 1.26 & 1.15 & 1.10 & 1.02 & 0.92 \\
\hline 803 & 2.98 & 2.83 & 2.57 & 2.09 & 1.85 & 1.67 & 1.64 & 1.56 & 1.42 & 1.46 & 1.34 & 1.23 \\
\hline
\end{tabular}

* The cylinder-concave clearances of the combine were C1 (12.5/5.5), C2 (13/6) and C3 (16/7) mm front/rear for rice crop. 


\section{c- Cleaning loses:}

Generally, the cleaning losses increased by increasing both feed rate, operating forward speed and threshing drum speed, and the cleaning decreased by decreasing the cylinder concave clearance. Data in Table (5) show that increasing feed rate from 2000 to $3000 \mathrm{~kg} / \mathrm{h}$ at drum speed of $803 \mathrm{rpm}$, increased cleaning losses from 0.53 to $0.55 \%$ at grain moisture content $21 \%$.

Thus, the sequence of the cylinder-concave clearance to the least values of cleaning losses was found to be as the following order; $\mathrm{C}_{1}(12.5 / 5.5)$, $\mathrm{C}_{2}(13 / 6)$ and $\mathrm{C}_{3}(16 / 7) \mathrm{mm}$ at grain moisture content $21 \%$, feed rate $2000 \mathrm{~kg} / \mathrm{h}$ and drum speed $803 \mathrm{rpm}$.

Also, the sequence of the four different threshing and separation drums to the least percentage value of cleaning losses as found to be as the following order: developed vane rotors ( 7 teeth), developed vane rotors (10 teeth), developed vane rotors (15 teeth) and original vane rotors (15 teeth).

\section{d- Total grain losses:}

From the previous analysis and results obtained, the total grain losses including both unthreshed grain, damage and cleaning losses were illustrated in Table (6). It can be noticed that the minimum total grain losses of $1.68 \%$ will be achieved at grain moisture content $21 \%$, drum speed of $500 \mathrm{rpm}$, feed rate of $2000 \mathrm{~kg} / \mathrm{h}$, operating forward speed of $1.22 \mathrm{~km} / \mathrm{h}$ and cylinder-concave clearance $\left(\mathrm{C}_{1}\right)$ for the development vane rotors (7 teeth).

\section{Effect of some operating parameters on efficiencies:}

Both the threshing efficiency, grain quality an cleaning efficiency are affected by different operating parameters such as grain moisture content, feed rate, operating forward speed, threshing drum speed,... etc. 
Table (5): Effect of cylinder-concave clearance on cleaning losses (\%) at three cylinder speeds and two feed rates for rice crop (Giza 171) at moisture content $21 \%$.

\begin{tabular}{|c|c|c|c|c|c|c|c|c|c|c|c|c|}
\hline \multirow{4}{*}{$\begin{array}{c}\text { Cylinder } \\
\text { speed, r.p.m. }\end{array}$} & \multicolumn{12}{|c|}{ Unthreshing grain, $\%$} \\
\hline & \multicolumn{3}{|c|}{ Original rotor (15 teeth) } & \multicolumn{3}{|c|}{ Developed rotor (15 teeth) } & \multicolumn{3}{|c|}{ Developed rotor (10 teeth) } & \multicolumn{3}{|c|}{ Developed rotor (7 teeth) } \\
\hline & \multicolumn{12}{|c|}{ Feed rate $=2000 \mathrm{~kg} / \mathrm{h}$ at forward speed $=1.22 \mathrm{~km} / \mathrm{h}$} \\
\hline & $\mathrm{C} 1$ & $\mathrm{C} 2$ & C3 & $\mathrm{C} 1$ & $\mathrm{C} 2$ & C3 & $\mathrm{C} 1$ & $\mathrm{C} 2$ & C3 & $\mathrm{C} 1$ & $\mathrm{C} 2$ & C3 \\
\hline 500 & 0.48 & 0.50 & 0.52 & 0.32 & 0.34 & 0.35 & 0.30 & 0.32 & 0.33 & 0.29 & 0.30 & 0.31 \\
\hline 630 & 0.51 & 0.52 & 0.54 & 0.35 & 0.36 & 0.38 & 0.33 & 0.34 & 0.36 & 0.31 & 0.32 & 0.35 \\
\hline 803 & 0.53 & 0.56 & 0.57 & 0.37 & 0.38 & 0.42 & 0.35 & 0.37 & 0.39 & 0.33 & 0.35 & 0.37 \\
\hline \multirow{2}{*}{$\begin{array}{c}\text { Cylinder } \\
\text { speed, r.p.m. }\end{array}$} & \multicolumn{12}{|c|}{ Feed rate $=3000 \mathrm{~kg} / \mathrm{h}$ ar forward speed $=1.91 \mathrm{~km} / \mathrm{h}$} \\
\hline & $\mathrm{C} 1$ & $\mathrm{C} 2$ & C3 & $\mathrm{C} 1$ & $\mathrm{C} 2$ & $\mathrm{C} 3$ & $\mathrm{C} 1$ & $\mathrm{C} 2$ & $\mathrm{C} 3$ & $\mathrm{C} 1$ & $\mathrm{C} 2$ & $\mathrm{C} 3$ \\
\hline 500 & 0.50 & 0.52 & 0.54 & 0.34 & 0.37 & 0.38 & 0.33 & 0.35 & 0.36 & 0.30 & 0.32 & 0.34 \\
\hline 630 & 0.53 & 0.55 & 0.57 & 0.38 & 0.39 & 0.43 & 0.35 & 0.37 & 0.39 & 0.33 & 0.35 & 0.37 \\
\hline 803 & 0.55 & 0.57 & 0.59 & 0.41 & 0.43 & 0.45 & 0.38 & 0.40 & 0.41 & 0.37 & 0.36 & 0.38 \\
\hline
\end{tabular}

* The cylinder-concave clearances of the combine were C1 (12.5/5.5), C2 (13/6) and C3 (16/7) mm front/rear for rice crop. 
Table (6): Effect of cylinder-concave clearance on total losses (\%) (Unthreshed grain, Grain damage and cleaning losses) at three cylinder speeds and two feed rates for rice crop (Giza 171) at moisture content $21 \%$ ).

\begin{tabular}{|c|c|c|c|c|c|c|c|c|c|c|c|c|}
\hline \multirow{4}{*}{$\begin{array}{c}\text { Cylinder } \\
\text { speed, r.p.m. }\end{array}$} & \multicolumn{12}{|c|}{ Unthreshing grain, $\%$} \\
\hline & \multicolumn{3}{|c|}{ Original rotor (15 teeth) } & \multicolumn{3}{|c|}{ Developed rotor (15 teeth) } & \multicolumn{3}{|c|}{ Developed rotor (10 teeth) } & \multicolumn{3}{|c|}{ Developed rotor ( 7 teeth) } \\
\hline & \multicolumn{12}{|c|}{ Feed rate $=2000 \mathrm{~kg} / \mathrm{h}$ at forward speed $=1.22 \mathrm{~km} / \mathrm{h}$. } \\
\hline & $\mathrm{C} 1$ & $\mathrm{C} 2$ & $\mathrm{C} 3$ & $\mathrm{C} 1$ & $\mathrm{C} 2$ & $\mathrm{C} 3$ & $\mathrm{C} 1$ & $\mathrm{C} 2$ & $\mathrm{C} 3$ & $\mathrm{C} 1$ & $\mathrm{C} 2$ & $\mathrm{C} 3$ \\
\hline 500 & 5.04 & 5.08 & 5.17 & 2.34 & 2.43 & 2.42 & 2.04 & 2.05 & 2.17 & 1.68 & 1.74 & 1.87 \\
\hline 630 & 5.23 & 5.27 & 5.42 & 2.51 & 2.56 & 2.61 & 2.26 & 2.31 & 2.37 & 1.81 & 1.89 & 2.07 \\
\hline 803 & 5.35 & 5.45 & 5.54 & 2.77 & 2.78 & 2.84 & 2.48 & 2.59 & 2.66 & 1.88 & 2.08 & 2.16 \\
\hline \multirow{2}{*}{$\begin{array}{c}\text { Cylinder } \\
\text { speed, r.p.m. }\end{array}$} & \multicolumn{12}{|c|}{ Feed rate $=3000 \mathrm{~kg} / \mathrm{h}$ ar forward speed $=1.91 \mathrm{~km} / \mathrm{h}$. } \\
\hline & $\mathrm{C} 1$ & $\mathrm{C} 2$ & $\mathrm{C} 3$ & $\mathrm{C} 1$ & $\mathrm{C} 2$ & $\mathrm{C} 3$ & $\mathrm{C} 1$ & $\mathrm{C} 2$ & $\mathrm{C} 3$ & $\mathrm{C} 1$ & $\mathrm{C} 2$ & $\mathrm{C} 3$ \\
\hline 500 & 5.48 & 5.56 & 5.57 & 2.92 & 2.95 & 2.96 & 2.38 & 2.53 & 2.64 & 2.03 & 2.21 & 2.31 \\
\hline 630 & 5.68 & 5.85 & 5.81 & 3.05 & 3.12 & 3.16 & 2.47 & 2.69 & 2.77 & 2.15 & 2.32 & 2.45 \\
\hline 803 & 5.82 & 5.95 & 5.89 & 3.32 & 3.35 & 3.41 & 2.78 & 2.89 & 2.93 & 2.43 & 2.56 & 2.69 \\
\hline
\end{tabular}

* The cylinder-concave clearances of the combine were C1 (12.5/5.5), C2 (13/6) and C3 (16/7) mm front/rear for rice crop. 
Generally, the threshing efficiency increased by decreasing the feed rate and operating forward speed, and threshing efficiency decreased by decreasing threshing drum speed, increasing cylinder-concave clearance. Fig. (6) show that increasing the threshing drum speed from 500 to 803 $\mathrm{rpm}$ at feed rate of $2000 \mathrm{~kg} / \mathrm{h}$ and grain moisture content $21 \%$, increased the threshing efficiency from 98.34 to $99.58 \%$ for the developed rotor ( 7 teeth). On the other side, increasing the feed rate from 2000 to $3000 \mathrm{~kg} / \mathrm{h}$ at constant drum speed of $500 \mathrm{rpm}$ at grain 99.34 to $99.20 \%$ for the developed rotor ( 7 teeth). The grain quality increased by decreasing feed rate, operating forward speed and threshing drum speed, and the grain quality decreased by decreasing cylinder-concave clearance. Fig. (7) show that increasing the threshing drum speed from 500 to $803 \mathrm{rpm}$ at feed rate of $2000 \mathrm{~kg} / \mathrm{h}$ and grain moisture content $21 \%$, decreased grain quality from 99.27 to $98.87 \%$, on the other side, increasing the feed rate from 2000 to $3000 \mathrm{~kg} / \mathrm{h}$ at constant drum speed of $500 \mathrm{rpm}$, grain moisture content $21 \%$, the grain quality decreased from 99.27 to $99.07 \%$ for the developed rotor (7 teeth).

The cleaning efficiency increased by decreasing feed rate, operating forward speed and threshing drum speed, and the cleaning efficiency decreased by increasing the cylinder-concave clearance. Fig. (8) show that increasing the threshing drum speed from 500 to $800 \mathrm{rpm}$ at feed rate of $2000 \mathrm{~kg} / \mathrm{h}$, grain moisture content $21 \%$, decreased cleaning efficiency from 99.70 to $99.65 \%$. On the other side increasing the feed rate from 2000 to $3000 \mathrm{~kg} / \mathrm{h}$ at constant drum speed of $500 \mathrm{rpm}$, grain moisture content $21 \%$, the cleaning efficiency decreased from 99.71 to $99.70 \%$ for the developed rotor ( 7 teeth). 


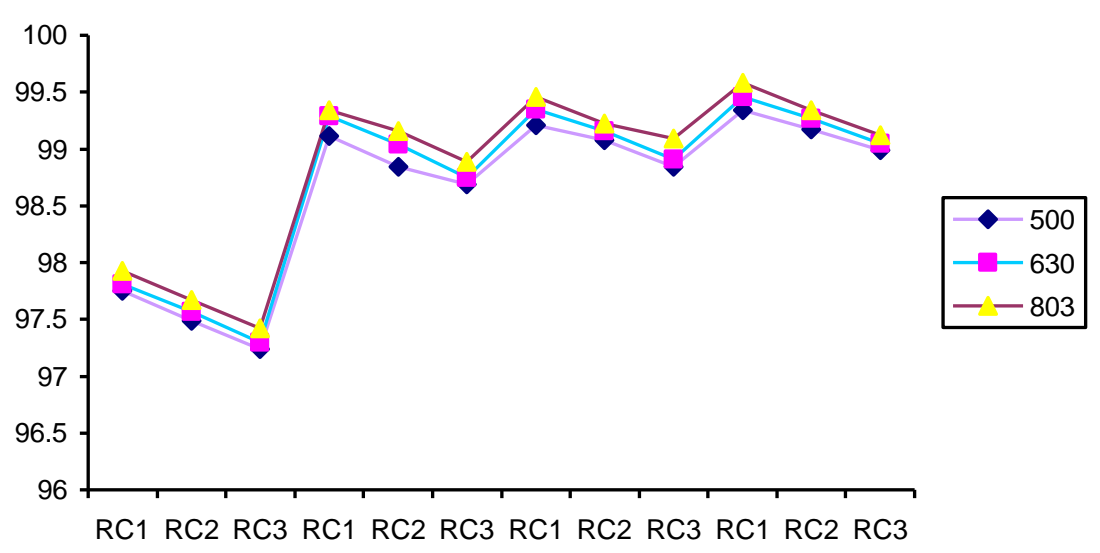

Cylinder speed, r.p.m.

(A) At feed rate $2000 \mathrm{~kg} / \mathrm{h}$.

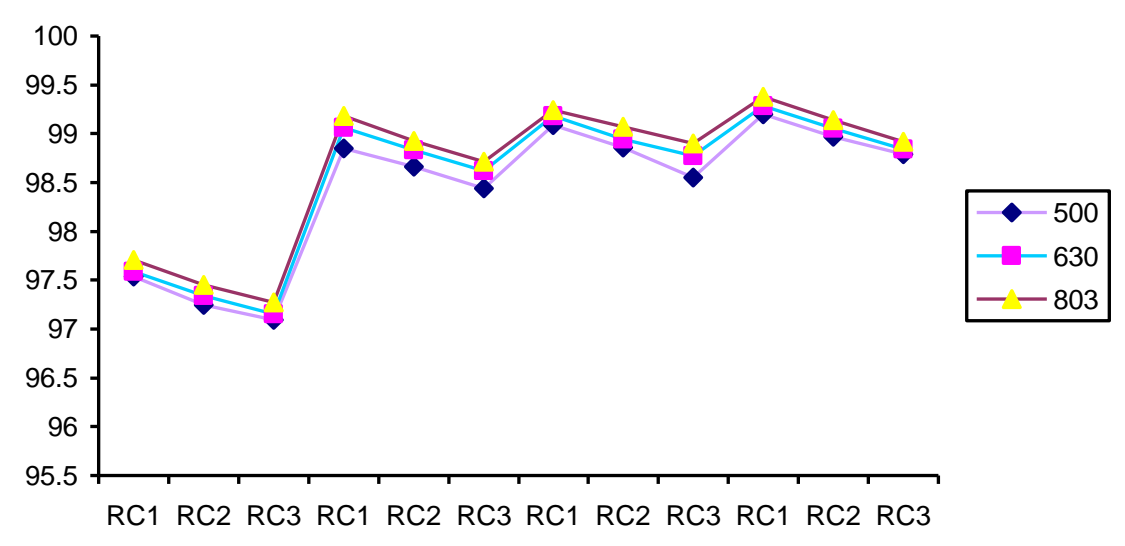

\section{Cylinder speed, r.p.m.}

(B) At feed rate $3000 \mathrm{~kg} / \mathrm{h}$.

Fig. (6): Effect of cylinder-concave clearance on threshing efficiency (\%) at three cylinder speeds and two feed rates for rice crop (Giza 171) at moisture content $21 \%$ 


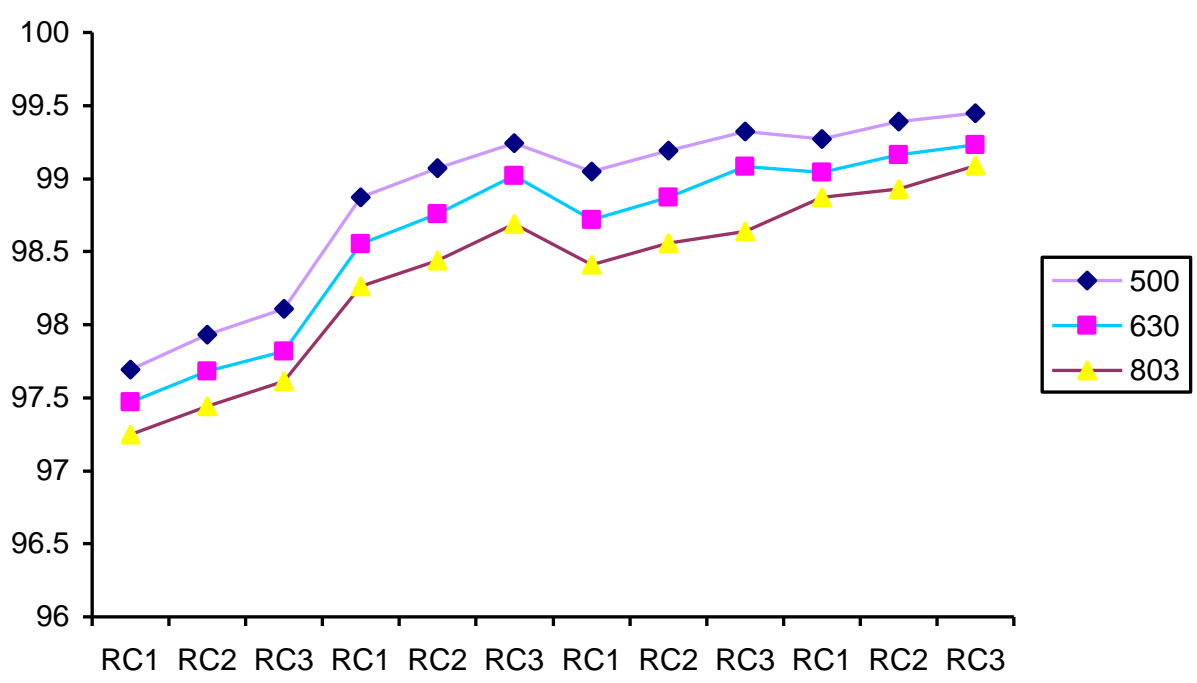

Cylinder speed, r.p.m.

(A) At feed rate $2000 \mathrm{~kg} / \mathrm{h}$.

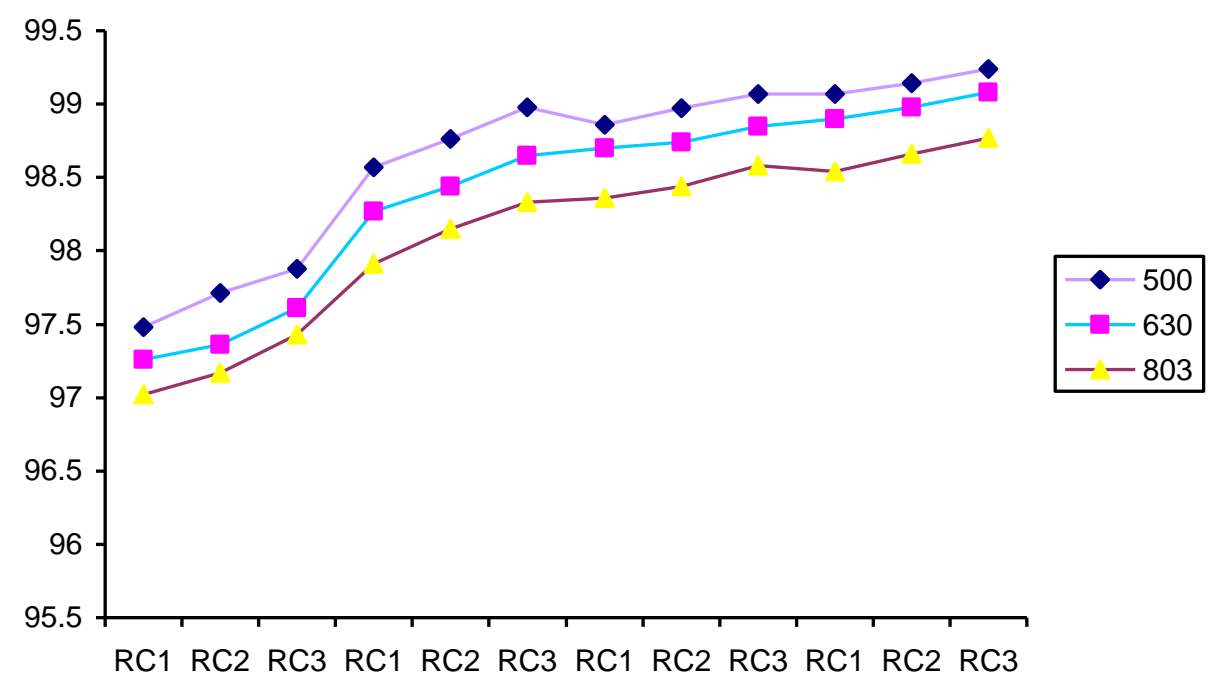

Cylinder speed, r.p.m.

(B) At feed rate $3000 \mathrm{~kg} / \mathrm{h}$.

Fig. (7): Effect of cylinder-concave clearance on grain quality (\%) at three cylinder speeds and two feed rates for rice crop (Giza 171) at moisture content $21 \%$ 


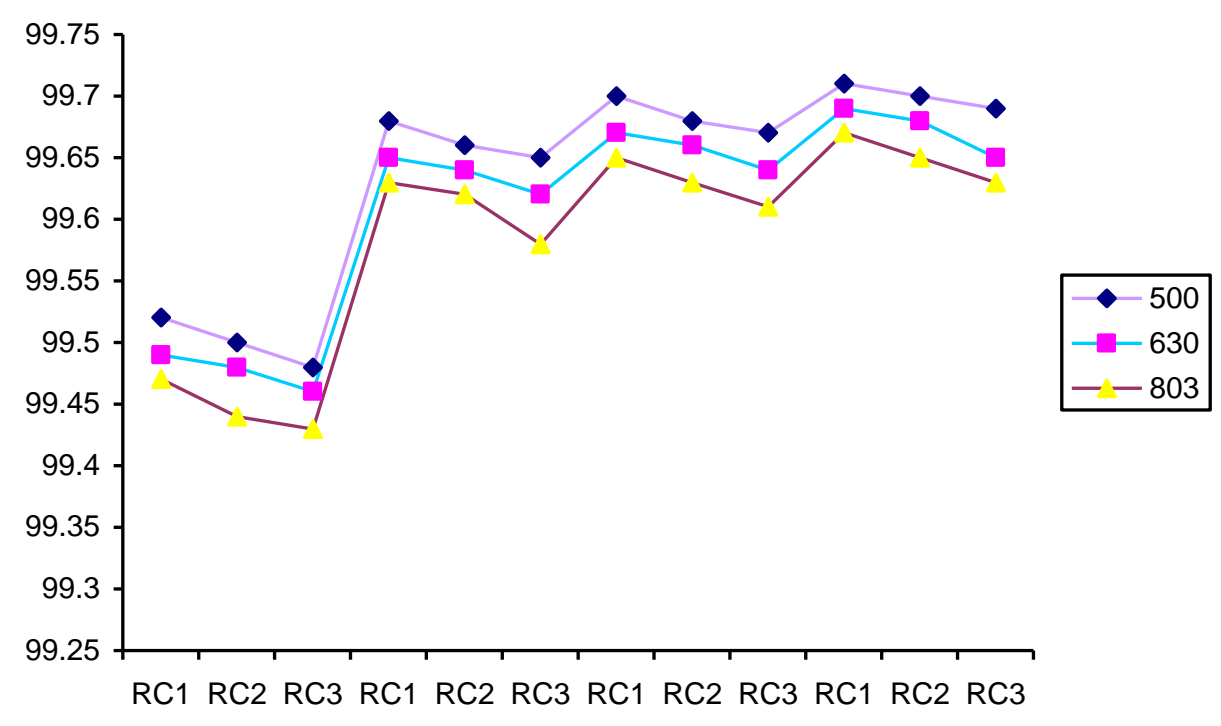

Cylinder speed, r.p.m.

(A) At feed rate $2000 \mathrm{~kg} / \mathrm{h}$.

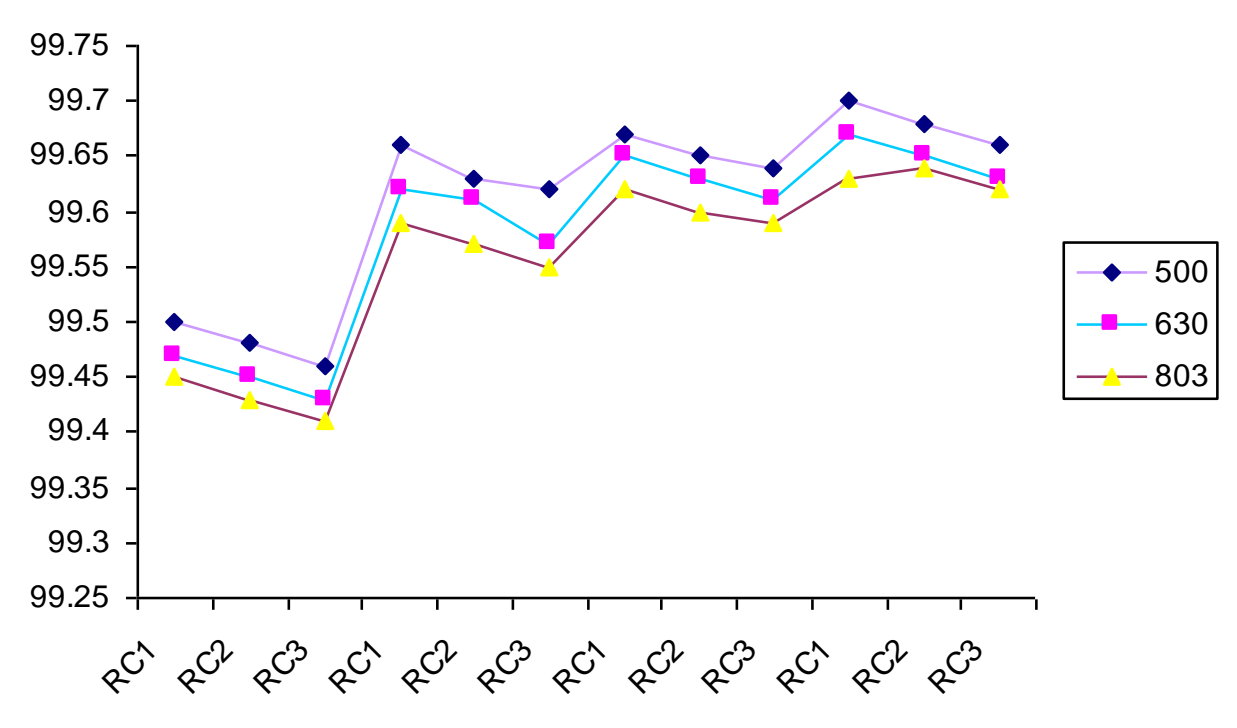

Cylinder speed, r.p.m.

(B) At feed rate $3000 \mathrm{~kg} / \mathrm{h}$.

Fig. (8): Effect of cylinder-concave clearance on cleaning efficiency (\%) at three cylinder speeds and two feed rates for rice crop (Giza 171) at moisture content $21 \%$ 


\section{3- Effect of operating parameters on power and energy requirements:}

From the results, the cylinder-concave clearance was adjusted on $\mathrm{C}_{1}$ $(12.5 / 5.5) \mathrm{mm}$, values of the actual field capacity, theoretical field capacity and the field efficiency for the different types of threshing and separation drums for the combine at grain moisture content $21 \%$ are found as shown in Tables (7) through (10).

According to Table (7) through (1) it is clear that the highest values of the actual field capacity was found to be as the developed vane rotors ( 7 teeth), it compare both the developed vane rotors (10 teeth), the developed vine rotors (15 teeth) and the original vane rotors (15 teeth). Also, from the Table (7) through (10) it is clear that the highest values of the field efficiency was found to be as the developed vine rotors ( 7 teeth), it compare both the developed vine rotors (10 teeth), the developed vine rotors (15 teeth) and the original vane rotors (15 teeth).

Tables (7) through (10) show the relation between drum speed and feed rate with power and energy requirements. Increasing feed rate from 2000 to $3000 \mathrm{~kg} / \mathrm{h}$ at drum speed of $500 \mathrm{rpm}$ and grain moisture content of $21 \%$, the power increased from $14.761+020.698 \mathrm{kw}$, and the energy requirement increased from 30.186 to $32.140 \mathrm{kw} . \mathrm{h} / \mathrm{fed}$. for the developed vine rotors ( 7 teeth). Increasing energy required by increasing feed rate is attributed to the excessive plants in the threshing chamber which represent more loads on the drum, resulting in more fuel consumption and energy. On the other side, increasing the drum speed from 500 to 803 $\mathrm{rpm}$ at constant feed rate of $2000 \mathrm{~kg} / \mathrm{h}$ and grain moisture content of $21 \%$, increased the energy required from 30.186 to $32.147 \mathrm{kw} . \mathrm{h} / \mathrm{fed}$. The sequence of the four threshing and separation drums to the least values of the required power and energy are found to be as the following order: developed vine rotors ( 7 teeth), developed vine rotors (10 teeth), developed vine rotors (15 teeth) and original vine rotors (15 teeth). 
Table (7): Effect of operating forward speed and cylinder speeds for combine (class crop tiger) with the original vane rotors (15 teeth) on the actual field capacity, field efficiency, power required and energy requirements.

\begin{tabular}{|c|c|c|c|c|c|c|c|c|}
\hline \multirow{2}{*}{$\begin{array}{l}\text { Cylinder } \\
\text { speed, } \\
\text { r.p.m. }\end{array}$} & \multirow{2}{*}{$\begin{array}{c}\text { Forward } \\
\text { operating } \\
\text { speed, } \\
\mathrm{km} / \mathrm{h}\end{array}$} & \multirow[b]{2}{*}{$\begin{array}{l}\text { Theoretical } \\
\text { F.C., fed./h }\end{array}$} & \multirow{2}{*}{$\begin{array}{l}\text { Actual } \\
\text { field } \\
\text { capacity, } \\
\text { fed./h }\end{array}$} & \multirow{2}{*}{$\begin{array}{c}\text { The field } \\
\text { efficiency, } \\
\%\end{array}$} & \multirow{2}{*}{$\begin{array}{c}\text { Measured } \\
\text { fuel } \\
\text { consumption, } \\
\text { L/h }\end{array}$} & \multirow{2}{*}{$\begin{array}{c}\text { Power } \\
\text { required, } \\
\mathrm{kw}\end{array}$} & \multicolumn{2}{|c|}{ Energy requirements } \\
\hline & & & & & & & kw.h/fed. & MJ/fed. \\
\hline \multirow{2}{*}{500} & 1.22 & 0.610 & 0.429 & 70.33 & 6.90 & 22.142 & 51.613 & 185.807 \\
\hline & 1.91 & 0.955 & 0.531 & 55.60 & 8.70 & 27.918 & 52.576 & 189.274 \\
\hline \multirow{2}{*}{630} & 1.22 & 0.610 & 0.440 & 72.13 & 7.20 & 23.105 & 52.511 & 189.040 \\
\hline & 1.91 & 0.955 & 0.548 & 57.38 & 9.10 & 29.202 & 53.288 & 191.837 \\
\hline \multirow{2}{*}{803} & 1.22 & 0.610 & 0.453 & 74.26 & 7.50 & 24.067 & 53.128 & 191.261 \\
\hline & 1.91 & 0.955 & 0.571 & 59.79 & 9.70 & 31.127 & 54.513 & 196.247 \\
\hline
\end{tabular}

* Field dimension for 4.1 feddan (length $383 \mathrm{~m} x$ width $44.85 \mathrm{~m}$ ).

** The dimension for the plot were $383 \mathrm{~m}$ in length and $7.48 \mathrm{~m}$ in width.

*** Cylinder-concave, clearance C1 (12.5/5.5 mm).

$* * * *$ The working width for combine (class crop tiger) $=2.10 \mathrm{~m}$. 
Table (8): Effect of operating forward speeds and cylinder speeds for combine (class crop tiger) with the developed vane rotors (15 teeth) on the actual field capacity, field efficiency, power required and energy requirements..

\begin{tabular}{|c|c|c|c|c|c|c|c|c|}
\hline \multirow{2}{*}{$\begin{array}{l}\text { Cylinder } \\
\text { speed, } \\
\text { r.p.m. }\end{array}$} & \multirow{2}{*}{$\begin{array}{c}\text { Forward } \\
\text { operating } \\
\text { speed, } \\
\mathrm{km} / \mathrm{h}\end{array}$} & \multirow[b]{2}{*}{$\begin{array}{l}\text { Theoretical } \\
\text { F.C., fed./h }\end{array}$} & \multirow{2}{*}{$\begin{array}{l}\text { Actual } \\
\text { field } \\
\text { capacity, } \\
\text { fed./h }\end{array}$} & \multirow{2}{*}{$\begin{array}{l}\text { The field } \\
\text { efficiency, } \\
\%\end{array}$} & \multirow{2}{*}{$\begin{array}{c}\text { Measured } \\
\text { fuel } \\
\text { consumption, } \\
\text { L/h }\end{array}$} & \multirow{2}{*}{$\begin{array}{c}\text { Power } \\
\text { required, } \\
\text { kw }\end{array}$} & \multicolumn{2}{|c|}{ Energy requirements } \\
\hline & & & & & & & kw.h/fed. & MJ/fed. \\
\hline \multirow{2}{*}{500} & 1.22 & 0.610 & 0.460 & 75.41 & 5.90 & 18.933 & 41.159 & 148.172 \\
\hline & 1.91 & 0.955 & 0.577 & 60.42 & 7.80 & 25.030 & 43.379 & 156.164 \\
\hline \multirow{2}{*}{630} & 1.22 & 0.610 & 0.468 & 76.72 & 6.20 & 19.896 & 42.513 & 153.047 \\
\hline & 1.91 & 0.955 & 0.597 & 62.51 & 8.20 & 26.314 & 44.077 & 158.677 \\
\hline \multirow{2}{*}{803} & 1.22 & 0.610 & 0.481 & 78.85 & 6.50 & 20.858 & 43.364 & 156.110 \\
\hline & 1.91 & 0.955 & 0.620 & 64.92 & 8.70 & 27.918 & 45.029 & 162.104 \\
\hline
\end{tabular}

* Field dimension for 4.1 feddan (length $383 \mathrm{~m} \mathrm{x}$ width $44.85 \mathrm{~m}$ ).

** The dimension for the plot were $383 \mathrm{~m}$ in length and $7.48 \mathrm{~m}$ in width.

$* * *$ Cylinder-concave, clearance C1 (12.5/5.5 mm).

$* * * *$ The working width for combine (class crop tiger) $=2.10 \mathrm{~m}$. 
Table (9): Effect of operating forward speed and cylinder speeds for combine (class crop tiger) with the developed vane rotors (10 teeth) on the actual field capacity, field efficiency, power required and energy requirements.

\begin{tabular}{|c|c|c|c|c|c|c|c|c|}
\hline \multirow{2}{*}{$\begin{array}{l}\text { Cylinder } \\
\text { speed, } \\
\text { r.p.m. }\end{array}$} & \multirow{2}{*}{$\begin{array}{c}\text { Forward } \\
\text { operating } \\
\text { speed, } \\
\mathrm{km} / \mathrm{h}\end{array}$} & \multirow[b]{2}{*}{$\begin{array}{l}\text { Theoretical } \\
\text { F.C., fed./h }\end{array}$} & \multirow{2}{*}{$\begin{array}{l}\text { Actual } \\
\text { field } \\
\text { capacity, } \\
\text { fed./h }\end{array}$} & \multirow{2}{*}{$\begin{array}{c}\text { The field } \\
\text { efficiency, } \\
\%\end{array}$} & \multirow{2}{*}{$\begin{array}{c}\text { Measured } \\
\text { fuel } \\
\text { consumption, } \\
\mathrm{L} / \mathrm{h}\end{array}$} & \multirow{2}{*}{$\begin{array}{c}\text { Power } \\
\text { required, } \\
\text { kw }\end{array}$} & \multicolumn{2}{|c|}{ Energy requirements } \\
\hline & & & & & & & kw.h/fed. & MJ/fed. \\
\hline \multirow{2}{*}{500} & 1.22 & 0.610 & 0.473 & 77.54 & 5.10 & 16.366 & 34.600 & 124.560 \\
\hline & 1.91 & 0.955 & 0.599 & 62.72 & 7.00 & 22.463 & 37.501 & 135.004 \\
\hline \multirow{2}{*}{630} & 1.22 & 0.610 & 0.842 & 79.02 & 5.40 & 17.329 & 35.952 & 129.427 \\
\hline & 1.91 & 0.955 & 0.620 & 64.92 & 7.30 & 23.426 & 37.784 & 136.022 \\
\hline \multirow{2}{*}{803} & 1.22 & 0.610 & 0.492 & 80.65 & 5.70 & 18.291 & 37.177 & 133.837 \\
\hline & 1.91 & 0.955 & 0.648 & 67.85 & 7.80 & 25.030 & 38.626 & 139.054 \\
\hline
\end{tabular}

* Field dimension for 4.1 feddan (length $383 \mathrm{~m} \mathrm{x}$ width $44.85 \mathrm{~m}$ ).

** The dimension for the plot were $383 \mathrm{~m}$ in length and $7.48 \mathrm{~m}$ in width.

*** Cylinder-concave, clearance C1 (12.5/5.5 mm).

$* * * *$ The working width for combine (class crop tiger) $=2.10 \mathrm{~m}$. 
Table (10): Effect of operating forward speed and cylinder speeds for combine (class crop tiger) with the developed vane rotors ( 7 teeth) on the actual field capacity, field efficiency, power required and energy requirements.

\begin{tabular}{|c|c|c|c|c|c|c|c|c|}
\hline \multirow{2}{*}{$\begin{array}{l}\text { Cylinder } \\
\text { speed, } \\
\text { r.p.m. }\end{array}$} & \multirow{2}{*}{$\begin{array}{c}\text { Forward } \\
\text { operating } \\
\text { speed, } \\
\mathrm{km} / \mathrm{h}\end{array}$} & \multirow[b]{2}{*}{$\begin{array}{l}\text { Theoretical } \\
\text { F.C., fed./h }\end{array}$} & \multirow{2}{*}{$\begin{array}{l}\text { Actual } \\
\text { field } \\
\text { capacity, } \\
\text { fed./h }\end{array}$} & \multirow{2}{*}{$\begin{array}{c}\text { The field } \\
\text { efficiency, } \\
\%\end{array}$} & \multirow{2}{*}{$\begin{array}{c}\text { Measured } \\
\text { fuel } \\
\text { consumption, } \\
\text { L/h }\end{array}$} & \multirow{2}{*}{$\begin{array}{c}\text { Power } \\
\text { required, } \\
\text { kw }\end{array}$} & \multicolumn{2}{|c|}{ Energy requirements } \\
\hline & & & & & & & $\mathrm{kw} \cdot \mathrm{h} / \mathrm{fed}$. & MJ/fed. \\
\hline \multirow{2}{*}{500} & 1.22 & 0.610 & 0.489 & 80.16 & 4.60 & 14.761 & 30.186 & 108.670 \\
\hline & 1.91 & 0.955 & 0.644 & 67.43 & 6.45 & 20.698 & 32.140 & 115.704 \\
\hline \multirow{2}{*}{630} & 1.22 & 0.610 & 0.525 & 86.06 & 5.20 & 16.687 & 31.785 & 114.426 \\
\hline & 1.91 & 0.955 & 0.688 & 72.04 & 7.20 & 23.105 & 33.583 & 120.899 \\
\hline \multirow{2}{*}{803} & 1.22 & 0.610 & 0.564 & 92.46 & 5.65 & 18.131 & 32.147 & 115.729 \\
\hline & 1.91 & 0.955 & 0.710 & 78.64 & 7.60 & 24.388 & 34.349 & 123.656 \\
\hline
\end{tabular}

* Field dimension for 4.1 feddan (length $383 \mathrm{~m} x$ width $44.85 \mathrm{~m}$ ).

** The dimension for the plot were $383 \mathrm{~m}$ in length and $7.48 \mathrm{~m}$ in width.

*** Cylinder-concave, clearance C1 (12.5/5.5 mm).

$* * * *$ The working width for combine (class crop tiger) $=2.10 \mathrm{~m}$. 


\section{Effect of operating parameters on criterion cost:}

The criterion cost is considered the main indicator, which judges the evaluation of the four threshing and separation drums. Results in Table (11) shows that, the total costs per unit area are 314.75, 270.25, 240.50 and $223.50 \mathrm{LE} / \mathrm{fed}$. for the original vane rotors (15 teeth), developed vane rotors (15 teeth), developed vane rotors (10 teeth) and developed vane rotors (7 teeth). The sequence of the four threshing and separation drums to the least values of the cost per unit area was found to be as the following order; developed vane rotors ( 7 teeth), developed vane rotors (10 teeth), developed vane rotors (15 teeth) and original vane rotors (15 teeth). Also, results in Table (11) it was remarked that, better results were reached under operating conditions were drum speed of $500 \mathrm{rpm}$, fed rate of $200 \mathrm{~kg} / \mathrm{h}$, operating forward speed of $1.22 \mathrm{~km} / \mathrm{h}$, cylinder-concave clearance $\left(\mathrm{C}_{1}, 12.5 / 5.5 \mathrm{~mm}\right)$, energy required of $30.186 \mathrm{kw} . \mathrm{h} / \mathrm{fed}$., operating costs of $223.50 \mathrm{LE}$./fed., total grain losses of $1.68 \%$ and threshing efficiency of $99.34 \%$.

Table (11): Cost analysis for the different types of threshing and separation drums for the combine harvester (class crop tiger).

\begin{tabular}{|l|c|c|c|c|c|c|}
\hline \multicolumn{1}{|c|}{ Implements } & $\begin{array}{c}\text { Fixed } \\
\text { costs, } \\
\text { LE/h }\end{array}$ & $\begin{array}{c}\text { Variable } \\
\text { costs/ } \\
\text { LE/h }\end{array}$ & $\begin{array}{c}\text { Manufacture } \\
\text { costs, LE/h }\end{array}$ & $\begin{array}{c}\text { Total } \\
\text { costs, } \\
\text { LE/h }\end{array}$ & $\begin{array}{c}\text { Actual } \\
\text { field } \\
\text { capacity, } \\
\text { fed./h }\end{array}$ & $\begin{array}{c}\text { Total } \\
\text { costs, } \\
\text { LE/fed. }\end{array}$ \\
\hline $\begin{array}{l}\text { The original vane } \\
\text { rotors } \\
\text { (15 teeth) }\end{array}$ & 29.40 & 99.00 & 6.64 & 135.04 & 0.429 & 314.75 \\
\hline $\begin{array}{l}\text { The developed } \\
\text { vane rotors } \\
\text { (15 teeth) }\end{array}$ & 29.40 & 88.26 & 6.64 & 124.30 & 0.460 & 270.2 \\
\hline $\begin{array}{l}\text { The developed } \\
\text { vane rotors } \\
\text { (10 teeth) }\end{array}$ & 29.40 & 79.68 & 4.64 & 113.72 & 0.473 & 240.50 \\
\hline $\begin{array}{l}\text { The developed } \\
\text { vane rotors } \\
\text { (7 teeth) }\end{array}$ & 29.40 & 76.45 & 3.44 & 109.29 & 0.489 & 223.50 \\
\hline
\end{tabular}

* Field dimension for 4.1 feddan (length $383 \mathrm{~m} x$ width $44.85 \mathrm{~m}$ ). ** The dimension for the plot were $383 \mathrm{~m}$ in length and $7.48 \mathrm{~m}$ in width. *** Cylinder-concave, clearance C1 (12.5/5.5 mm). $* * * *$ The working width for combine (class crop tiger) $=2.10 \mathrm{~m}$. 


\section{CONCLUSION}

The obtained results from the present investigation could be summarized of follow:

1- The unthreshed grain increased by increasing both feed rate and operating forward speed, and the unthreshed grain decreased by increasing threshing drum speed, decreasing the cylinder-concave clearance.

2- The grain damage increased by increasing both feed rate, operating forward speed and threshing drum speed and it decreased by increasing the cylinder-concave clearance.

3- The cleaning losses increased by increasing both feed rate, operating forward speed and threshing drum speed and it decreased by deceasing the cylinder-concave clearance.

4- The minimum total grain losses of $1.68 \%$ will be achieved at grain moisture content $21 \%$, threshing drum speed of $500 \mathrm{rpm}(17.0 \mathrm{~m} / \mathrm{s})$, feed rate of $2000 \mathrm{~kg} / \mathrm{h}$, operating forward speed of $1.22 \mathrm{~km} / \mathrm{h}$ and cylinder-concave clearance $(\mathrm{C} 1,12.5 / 5.5 \mathrm{~m})$ for the development vane rotors (7 teeth).

5- The threshing efficiency increased by decreasing the feed rate and operating forward speed, and it decreased by decreasing the threshing drum speed, increasing the cylinder-concave clearance.

6- The grain quality increased by decreasing the feed rate, operating, forward speed and threshing drum speed, and it decreased by decreasing the cylinder-concave clearance.

7- The cleaning efficiency increased by decreasing the feed rate, operating forward speed and threshing forward speed, and it decreased by increasing the cylinder-concave clearance.

8- The highest values of the actual field capacity was found to be as the developed vane rotors ( 7 teeth), it compare both the developed vane rotors (10 teeth), developed vane rotors (15 teeth) and original vane rotors (15 teeth).

9- The least values of the required energy was found to be as the developed vine rotors ( 7 teeth), it compare both the developed vane rotors (10 teeth), developed vine rotors (15 teeth) and original vane rotors (15 teeth).

10- The least values of the operating costs was found to be as the 
developed rotor ( 7 teeth), it compare both the developed rotor (10 teeth), the developed rotor (15 teeth) and the original rotor (15 teeth).

11- The better results were reached under operating conditions were threshing drum speed of $500 \mathrm{rpm}(17.0 \mathrm{~m} / \mathrm{s})$, feed rate of $2000 \mathrm{~kg} / \mathrm{h}$, operating forward speed $1.22 \mathrm{~km} / \mathrm{h}$, cylinder-concave clearance of $\mathrm{C}_{1}$ $(12.5 / 5.5 \mathrm{~m})$, energy required of $30.186 \mathrm{kw} . \mathrm{h} / \mathrm{fed}$; operating costs of $223.50 \mathrm{LE} / \mathrm{fed}$., total grain losses of $1.68 \%$ and threshing efficiency of $99.34 \%$, separation efficiency of $99.27 \%$ and clearing efficiency of $99.71 \%$ for the develop rotor (7 teeth).

12- The total operating costs per unit area are 314.75, 270.25, 240.5 and 223.50 LE.fed. for the original vane rotors (15 teeth), developed vane rotors (15 teeth), developed vane rotors (10 teeth) and developed vane rotors (7 teeth).

\section{REFERENCES}

Abd El-Mawla, H.A. 1996. Combine harvesting state of Art Misr. J. Ag. Eng., 13(2): 440-459.

Awady, M.N.; F.Y. Ghoniem and A.I. Hashish. 1982. A critical comparison between wheat combine harvesters under Egytpian conditions. Res. Bul. N o. 1920. Col. Ag. Ain Shams Univ. 13 p.

Awady, M.N.; G.H. El-Sayed; A.H.; Mohamed and I. Yehia. 2000. Evaluation of Barmel rice thresher. Misr J. of Ag. Eng., 17(3): 719-730.

El-Hadad, W.Z. 2000. A simplified design and performance study of threshing and winnowing machine suitable for small holdings. M. Sc. Thesis. Ag. Mech., Fac. of Ag. Kafr El-Sheikh, Tanta Univ.

El0Nakib, A.A.; Z.Y. Abdel Lateef; A.A. El-meseery and A.A. Khattab. 2003. Mechanical harvesting losses in rice crop using combine. $11^{\text {th }}$ Conference of Misr Society. Ag. Eng., 15 ${ }^{\text {th }}$ Oct. 889-907.

FAO. 1994. Testing an evaluation of Agricultural Machinery and Equipment. Principles and Pratices. Food and Agricultural Organization (FAO) Ag. Services Bulletin No. 110.

Hunt, D.R. 1983. Farm power and machinery management. $8^{\text {th }}$. Ed. Iowa State Univ. press. Ames. IA, USA; 364-368.

Ichikawa, T., T. Sugiyama. 1986. Development of a new combine equipped with screw type threshing and separating mechanisms. JARG, 20(1): 31-37. 
Kamel, O.M. 1999. Rice harvesting losses utilizing two different harvesting techniques of Japanese Cobmines Misr J. of Ag. Eng., 16(4): 237-251.

Kepner, R.A.; R. Bainer and E.L. Barger, 1982. Principles of farm machinery. $4^{\text {th }}$. Ed.John W. and Sons, Ins: 381-428.

Ministry of Agric., 2000. Mechanization projects. Management in the mechanical harvesting of main crops (wheat, barley and rice) Report Introduced to the Ministry of Ag. (Egypt) for Ag. December.

Morad, M.M. and T. Fouda, 2003. Development of Long-axial flow rice thresher shaft for minimum threshing power. Misr J Ag. Eng. 20(2): 391-404.

Sheruddin, B.A., A.I. Kjalil, H.J. Ghulam and A.K. Ghulam, 1991. Influence of timing and date of harvest on wheat grain loses. Ag Mech. In Asia, Africa and Latin America, 22(2): 56-58.

Simonyan, K.J. and K.C. Oni, 2001. Performance evaluation of a motorized locust bean decorticator. Journal of Agricultural Technology, 9(1): 55-56.

\section{الملخص العربي}

تطوير جهاز الداس فى آلة حصاد جامعة لتحسين كفاءة أدائها فى دراس الأرز

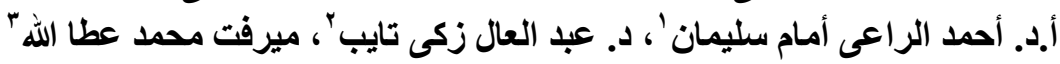

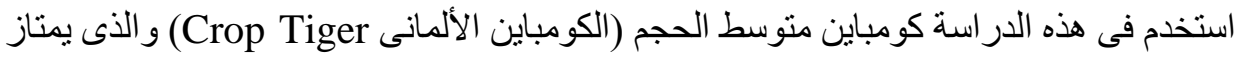

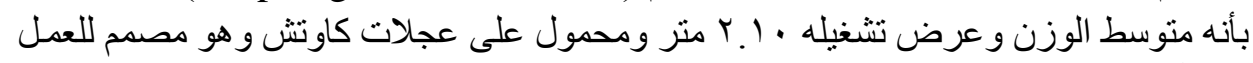

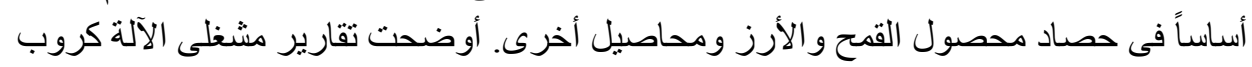

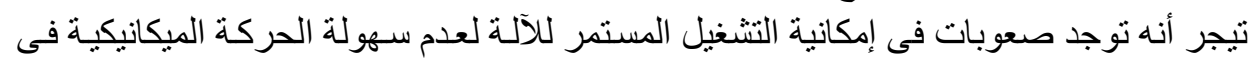

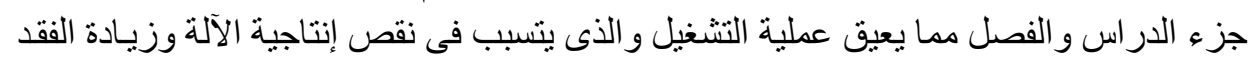

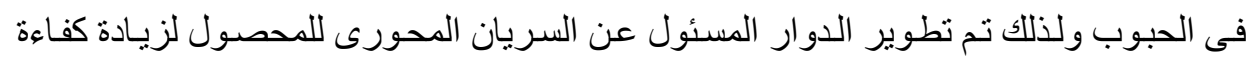

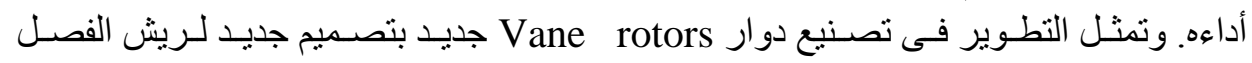

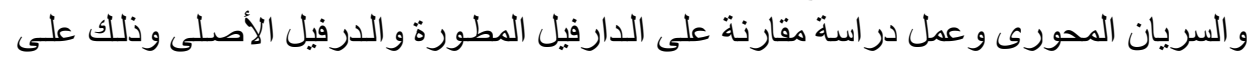

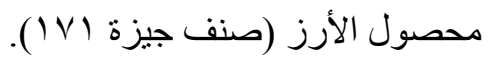

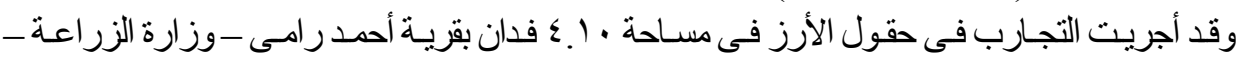

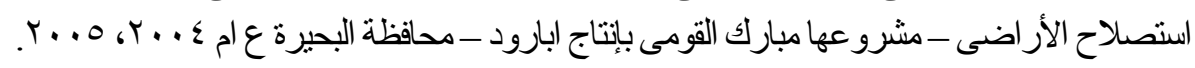

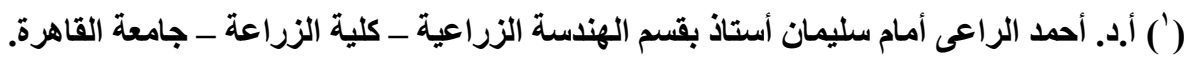

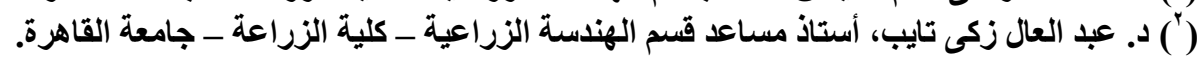

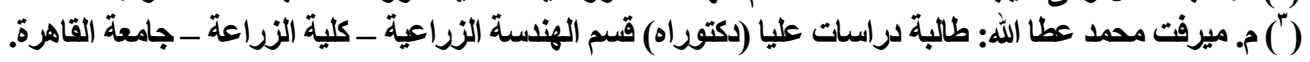




\section{مواصفات أسطوانة الاراس والفصل قبل وبعد التطوير:}

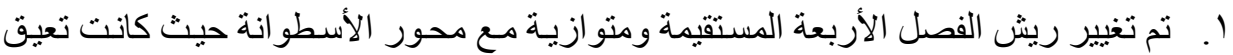

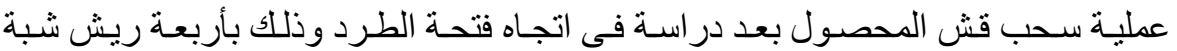

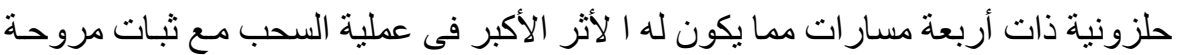

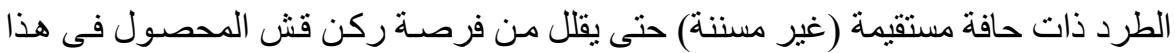
الحيز لحدوث الدوران.

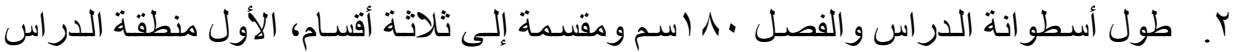
بطول ๑.0Vسم وتم استخدام الدرفيل ذو الأسنان Spike teeth drum فى در اس محصول

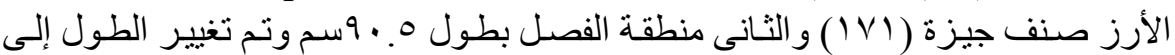

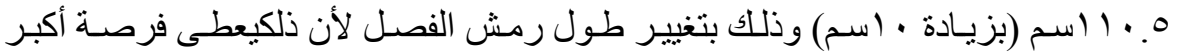

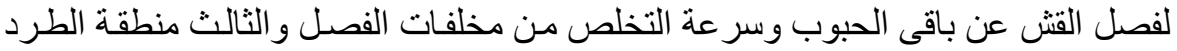

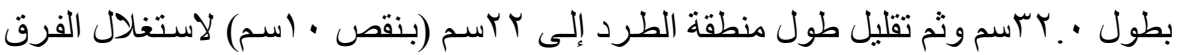

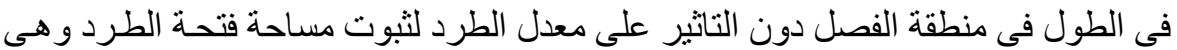

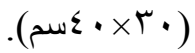

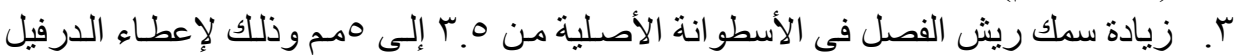

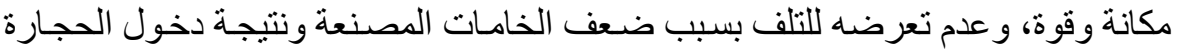
فى بعض الأحيان مع المحصول أو نتيجة فلك أحد عوارض فع الدر اس أثناء التشخيل.

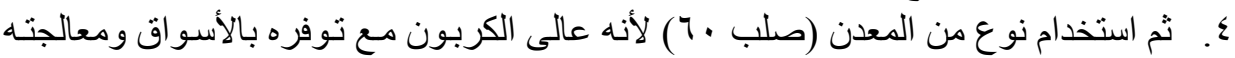

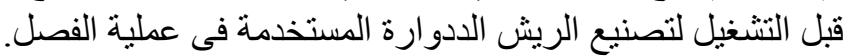

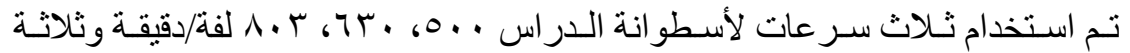

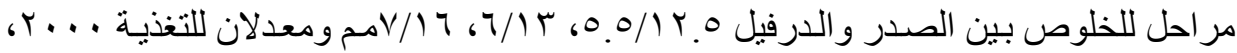

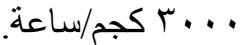

تم تقييم أداء الدرافيل المطورة والداءفيل الأصلى من خلال القياسات التالية: نسبة فو اقد الحبوب (فو اقد درفيل الدراس، فو اقد الفصل، فو اقد النظافة و الفو القد القد الكلية). كفاءة الآلة (كفاءة الدر اس، كفاءة الفصل، كفاءة التنظيف).

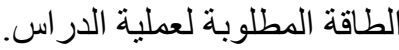

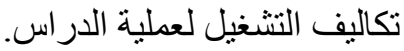

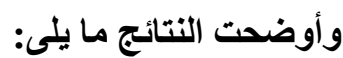

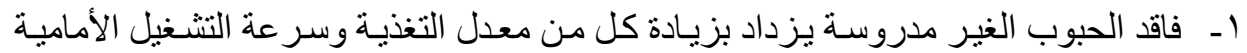

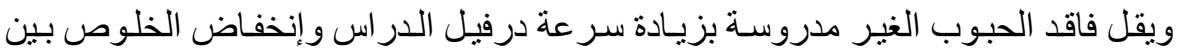

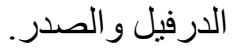
r- ـ فاقد الحبوب المدروسة يزداد بزيادة كل من معدل التخذية وسر عة التشغيل الأمامية وسـر عة

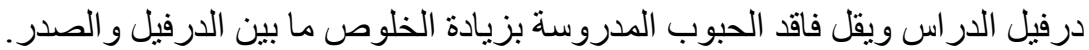

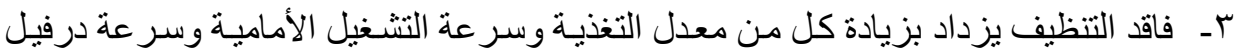

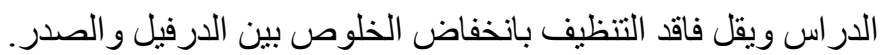
عـ - الفو اقد الكلية للحبوب تقل بانخفاض كل من معدل التغذية وسر عة التشـغيل الأمامية وسـر عة 


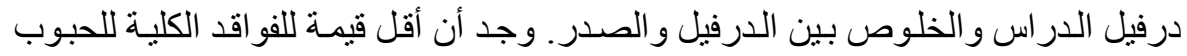

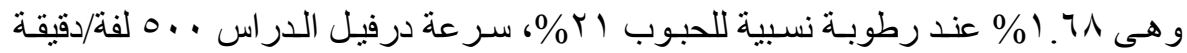

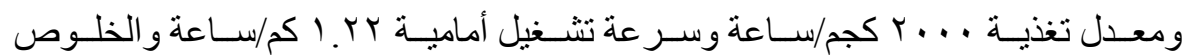

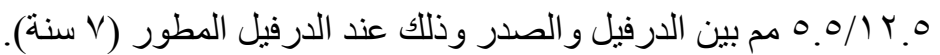

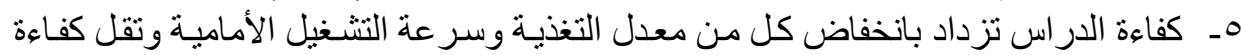

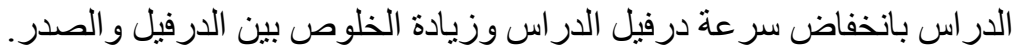

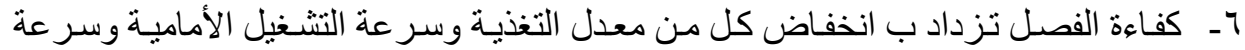

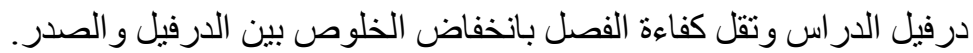

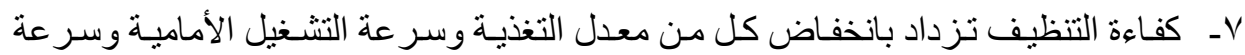

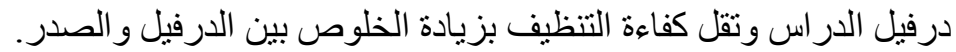

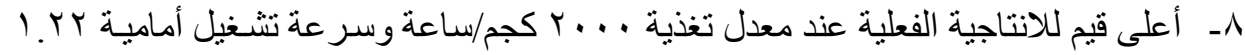

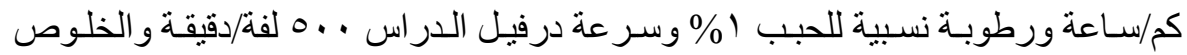

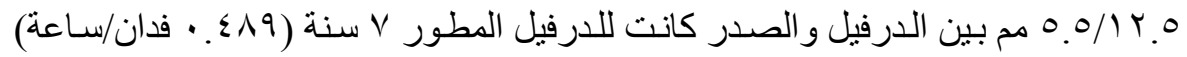

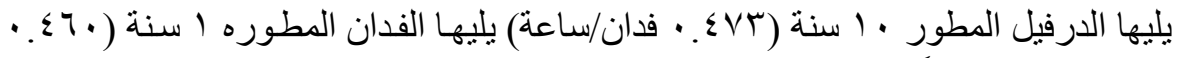

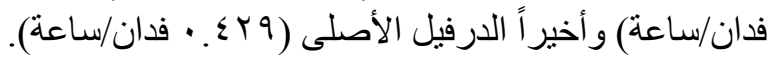

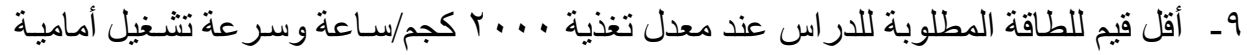

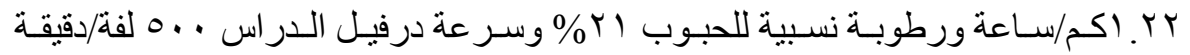

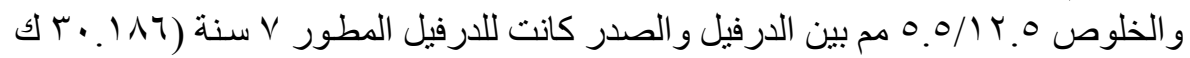

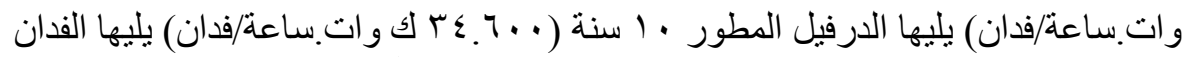

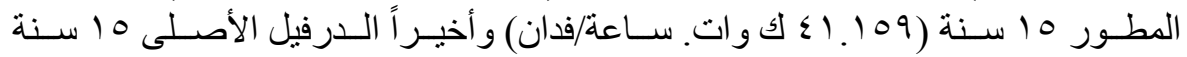

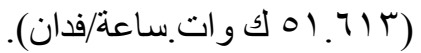

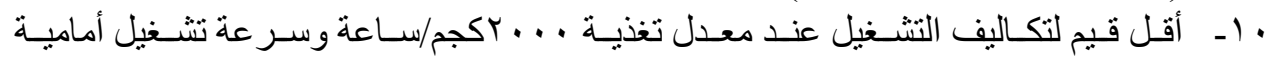

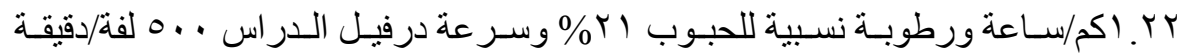

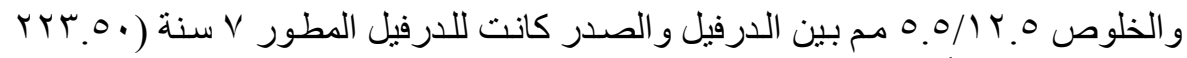

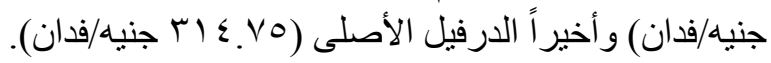

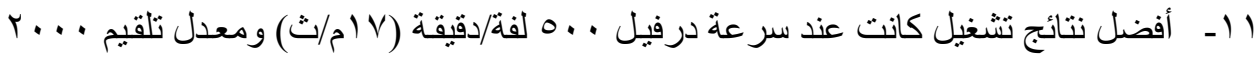

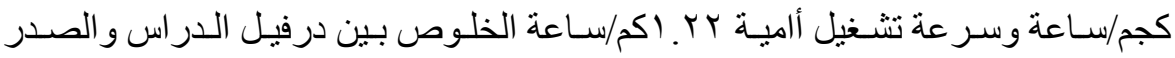

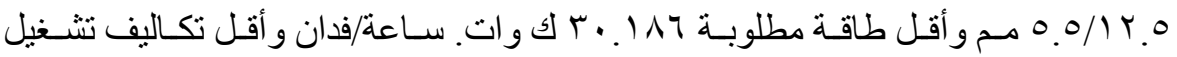

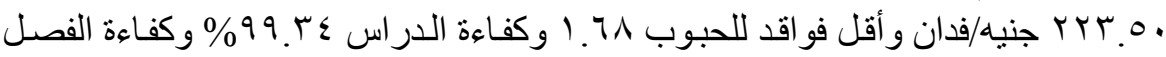

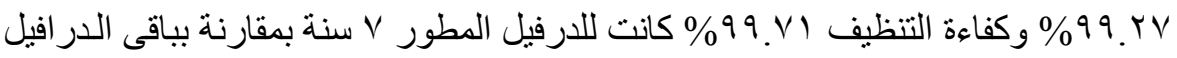
المطورة و الدرفيل الأصلى.

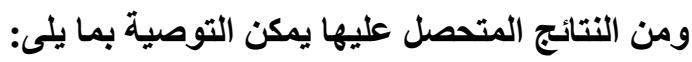

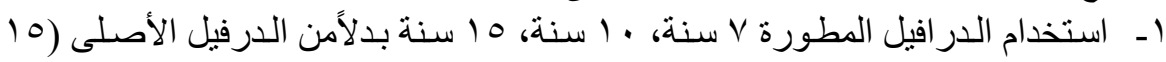
سنة) لجهاز الدراس و الفصل الآلة الحصاد الجامعة عند در اس الألة الأرز.

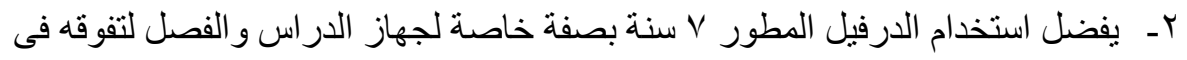

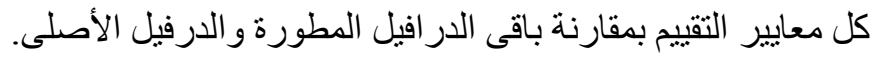

